\title{
Investability and Firm Value
}

\section{Todd Mitton}

Brigham Young University, Marriott School, Provo, UT 84602, USA

E-mail:tm@byu.edu

\section{Thomas O'Connor}

National University of Ireland Maynooth, Dept. of Economics, Finance, and Accounting, Co.

Kildare, Ireland

E-mail:thomas.g.oconnor@nuim.ie

\begin{abstract}
We study how investability, or openness to foreign equity investors, affects firm value in a sample of over 1,400 firms from 26 emerging markets. We find that, on average, investability is associated with a 9\% valuation premium (as measured by Tobin's q). This significant valuation premium persists in firm-fixed effects regressions, although the magnitude and robustness of the premium is somewhat lower. Analysis of the components of Tobin's q shows that firms that become investable experience significant increases in both market values and physical investment. These effects are strongest for firms that face country-level or firmlevel financial constraints prior to becoming investable.
\end{abstract}

Keywords: financial liberalisation, investability, foreign investors, Tobin's $q$

JEL classification: $G 15, F 36$

\section{Introduction}

When the stock of an emerging-market firm becomes available for foreign investment, the firm experiences changes in its stock market performance and its operating performance. Stocks of firms opening to foreign investment rise in price (see Henry, 2000a; Kim and Singal, 2000; Chari and Henry, 2004), and increase in return volatility (Bae et al., 2004). At the same time, firms that become open to foreign investment experience an increase in real investment (see Henry, 2000b; Mitton, 2006; Chari and Henry, 2008). In addition, firms opening to foreign investment appear to experience increases in sales growth, increases in profitability and efficiency, and lower leverage (Mitton, 2006).

Given the multiple effects of foreign investment on outcomes for firms, a natural question to ask is how opening to foreign investment ultimately impacts firm value. In this paper, we combine stock market data with financial statement data in order to study

We thank an anonymous referee and participants at the 6th INFINITI Conference in Dublin for helpful comments. Correspondence: Todd Mitton 
how openness to foreign investment affects firm value, as measured by Tobin's $q$. In contrast to previous studies of the effect of stock market liberalisation on stock prices, in our study we employ a firm-specific measure of liberalisation. Whereas Henry (2000a, 2000b), Kim and Singal (2000), and others measure liberalisation as a countrywide event, we follow Bae et al. (2004) and Mitton (2006) in measuring liberalisation by a firm's investability, which is a firm-specific measure of whether a stock is open to foreign investment.

Using investability as the measure of liberalisation rather than a country-specific date has at least three advantages. First, unlike country-specific measures, investability captures the fact that liberalisation tends to occur gradually among firms in a country, rather than all on one specific date. ${ }^{1}$ Second, the investability measure allows for a natural experiment in which the performance of investable firms can be compared with noninvestable firms while holding country characteristics constant. Third, since firms in the same country become investable at different times, the investability measure reduces concern about whether the observed effects of stock market liberalisation might be more properly ascribed to other reforms undertaken by the country at the time of liberalisation. Our study thus adds to our understanding of the effect of liberalisation on value by using a more precise measure of liberalisation.

The tests in our paper offer evidence on the effect of positive externalities of liberalisation on firm value. Previous literature hypothesises that when a firm becomes open to international investment, the increased scrutiny and analyst coverage that occurs can lead to improved governance of the firm, and that this monitoring in turn can increase firm value due to an improvement in operating performance or a reduction in expropriation (see, e.g., Stulz, 1999; Doidge et al., 2004; Bekaert et al., 2005; Mitton, 2006; Bae et al., 2006). In addition, liberalisation can lead to increases in market liquidity and efficiency, or to reductions in other country-specific risks, all of which can also lead to higher valuations. Positive externalities would imply a lasting increase in Tobin's $q$ due to all of these potential factors. In contrast, standard international asset pricing models do not necessarily predict that liberalisation leads to a lasting increase in Tobin's $q$. These models predict that when a country opens its domestic stock market to foreign investment, the country's cost of capital falls due to international risk sharing (see Bekaert and Harvey, 2000). This fall in the cost of capital should lead to increases in both stock prices and physical investment for liberaliseng firms (see, e.g., Stulz, 1999; Henry, 2000a, 2000b, 2003). Thus, while international asset pricing models predict increases in the components of $q$ (market values and book values of assets), they do not predict a net permanent increase in $q$ (although $q$ may rise or fall temporarily). We would therefore interpret a positive relationship between investability and $q$ as being consistent with the presence of positive externalities such as monitoring or market efficiency. ${ }^{2}$

We study the impact of investability on firm value in a sample of 1,432 firms from 26 emerging markets. We find that, on average, investable firms have higher Tobin's $q$ than noninvestable firms. On average, investability is associated with a valuation premium of roughly $9 \%$, and this valuation difference is statistically significant and persists even

\footnotetext{
${ }^{1}$ Bekaert and Harvey (2000) emphasise the gradual nature of liberalization using countrylevel measures rather than firm-level measures.

${ }^{2}$ This interpretation is similar to that in Gozzi et al. (2008), who argue that the bonding hypothesis would imply an enduring increase in firm value for firms that cross-list or raise capital in international markets.
} 
after controlling for size, industry, growth, and other firm characteristics. However, although simple averages and regression estimates indicate that investable firms have higher values, these results do not establish that investability has a causal effect on firm value. It may be that firms that already have, or are expected to have, higher values (for whatever reason) are those that are made available for foreign investment. To further address the issue of causality, we employ firm-fixed effects regressions to control for other sources of heterogeneity across firms. We find that in the firm-fixed effects regressions investability has a smaller effect on firm value, but that the effect is still statistically significant for at least one of our two measures of investability. Although the fixed effects regressions do not definitively establish a causal relationship between investability and firm value, we cautiously interpret our results as being consistent with positive externalities in the liberalisation process.

Additional results from the study are consistent with predictions of standard international asset pricing models. In additional tests we run firm-fixed effects regressions of the effect of investability on the components of Tobin's $q$, namely market values and book values of assets. We find that investability is associated with a large and statistically significant positive effect on both market values and book values. The pattern of changes in the components of $q$ is similar to the pattern documented in Gozzi et al. (2008) for firms that cross-list and raise capital internationally. Whereas existing studies document the positive effect of liberalisation on stock prices, our results add to existing findings by using the more-precise investability measure rather than a countrywide measure of liberalisation.

In a final series of tests we assess the role of financial constraints in the response of firms to becoming investable. Because stock market liberalisation increases the availability of financing for firms in emerging markets, the effects of liberalisation might be especially strong for firms that face financial constraints prior to liberalisation (see, e.g., Henry, 2003; Bekaert et al., 2005; Mitton, 2006). In particular, the presence of financial constraints prior to liberalisation could magnify both the stock price reaction to becoming investable and the increase in physical investment for investable firms. We measure financial constraints using firm-level measures (dividend payouts and investment-to-cash flow sensitivity). In general, we find that non-dividend payers and firms with greater investment-to-cash flow sensitivity have greater increases in market values and book values than do dividend-paying firms and firms with low investmentto-cash flow sensitivity. The finding that liberalisation especially benefits firms with financial constraints is consistent with the large literature emphasiseng the importance of financial development for economic growth.

Our paper contributes to a growing literature that studies how participation in international capital markets affects firm value as measured by Tobin's $q$. For example, Doidge et al. $(2004,2009)$ show that foreign firms with shares cross-listed in the USA have higher $q$ than firms that aren't cross listed. Gozzi et al. (2008) document trends in Tobin's $q$ when firms internationalise (i.e., cross-list, issue depositary receipts, or raise capital internationally) and find that $q$ rises before and during internationalisation but falls thereafter. King and Segal (2009) report similar patterns in $q$ for Canadian firms that cross-list. We establish the impact on Tobin's $q$ of a different aspect of internationalisation, the opening of a firm's stock to foreign investment.

The paper proceeds as follows. In the next section we describe the data used in the study and provide some summary statistics. In Section 3 we report results on the relation between investability and firm value. In Section 4 we discuss the role of financial constraints. Section 5 concludes. 


\section{Data and Summary Statistics}

We begin our study by sourcing an initial sample of all firms listed in the major markets of the IFC Emerging Market Database (EMDB) at any time between 1980 and 2003. The initial sample consists of 2,784 firms that are designated as investable at some point during the sample period as well as firms that are never designated as investable but are included in the less-restrictive IFC Global indices. To be included in the final sample, firms must also have financial data available in the Worldscope database. We are able to match 2,227 firms (80\%) of the initial sample of EMDB firms with Worldscope data. We then impose a minimum-data requirement on the set of matched firms. Firms that are investable at some point in the sample period are required to have financial data available at least one year before and one year after the year in which they are first investable. ${ }^{3}$ Firms that are never investable during the sample period are required to have financial data available one year before and one year after the median year in which firms are first investable in their respective country. Our final sample is outlined in Table 1. After imposing the minimum-data requirement, the final sample consists of 1,432 firms; 602 investable firms and 830 noninvestable firms from 26 countries. From our initial sample, we lose all firms from Egypt, Morocco, Slovakia, and Zimbabwe due to insufficient financial data. The number of sample firms per country varies significantly, ranging from a minimum of 1 (Venezuela) to a high of 183 (Korea). Korea provides the greatest number of investable firms (114), while Peru and Venezuela provide just one investable firm each.

We measure the openness of stocks to foreign investors using the 'investable' measure from the EMDB. The IFC designates a firm as investable if its stock is free from countrylevel and firm-level restrictions on foreign investment. The IFC also requires that the stocks have sufficient size and liquidity to be realistically available to foreign investors. We define a firm as investable in a given year if the firm's stock appears in the IFC investable index by December of that year. ${ }^{4}$ As a secondary measure of openness we use the 'degree open', a continuous variable ranging from zero (not open to foreign investors) to one (fully open to foreign investors). It should be acknowledged that the EMDB investable variables are measured with some noise. An 'investable' designation may not imply the same level for access for all stocks, and the IFC may have made occasional errors in the designations (see Edison and Warnock, 2003). In addition, there are likely firms, such as those from the so-called 'frontier' markets, that are given a degree-open measure of zero even though they are in reality at least partially open to foreign investment. Despite these limitations, it is unlikely that the noise in the EMDB measures introduces any significant bias in our tests.

Table 1 also presents four key dates for each country: the first year in which sample firms in each country are designated investable, the first year in which a closed-end

\footnotetext{
${ }^{3}$ There are firms in the sample that become investable more than once, i.e., in some periods they are designated noninvestable after being designated investable in earlier periods. In subsequent periods, these firms are once again designated investable. We require data to be available prior to their initial investable date.

${ }^{4}$ For some countries in the sample, official liberalisation occurred before introduction of the country's investable index, suggesting the possibility that the EMDB's investable designation could lag behind the true investability of certain firms. We address this possibility by repeating our tests excluding firms from these countries that were designated investable in the first year of the introduction of the country's index. Our results are materially unchanged.
} 
Table 1

Sample statistics by country

This table reports summary statistics of the sample by country. Investable dates are taken from the Emerging Markets Database (EMDB). All information on ADRs is sourced from the Bank of New York, Citibank, NYSE, and NASDAQ. The number of ADRs refers to the number of firms with ADRs that also have post-listing financial data. First country fund dates are taken from Bekaert et al. (2005) and Patro (2005). Official liberalisation dates are taken from Bekaert et al. (2005). Official liberalisation dates presented in italics represents those countries with pre- and post-liberalisation firm-level financial data.

\begin{tabular}{|c|c|c|c|c|c|c|c|c|}
\hline & \multicolumn{3}{|c|}{ Sample firms } & \multicolumn{3}{|c|}{ Key dates } & \multicolumn{2}{|c|}{ ADR } \\
\hline & Investable & $\begin{array}{c}\text { Non- } \\
\text { Investable }\end{array}$ & Total & $\begin{array}{c}\text { First } \\
\text { investable } \\
\text { in sample }\end{array}$ & $\begin{array}{l}\text { First } \\
\text { country } \\
\text { fund }\end{array}$ & $\begin{array}{c}\text { Official } \\
\text { liberalisation } \\
\text { date }\end{array}$ & $\begin{array}{c}\text { First } \\
\text { ADR in } \\
\text { sample }\end{array}$ & $\begin{array}{l}\text { Firms } \\
\text { with } \\
\text { ADRs }\end{array}$ \\
\hline Argentina & 7 & 3 & 10 & 1994 & 1991 & 1989 & 1997 & 1 \\
\hline Brazil & 31 & 49 & 80 & 1991 & 1992 & 1991 & 1994 & 16 \\
\hline Chile & 17 & 18 & 35 & 1990 & 1989 & 1992 & 1994 & 7 \\
\hline China & 25 & 26 & 51 & 1993 & 1992 & - & 1995 & 4 \\
\hline Colombia & 3 & 10 & 13 & 1995 & 1992 & 1991 & 1994 & 1 \\
\hline Czech R. & 4 & 24 & 28 & 1997 & 1994 & - & - & - \\
\hline Greece & 16 & 53 & 69 & 1990 & 1998 & 1987 & 2000 & 1 \\
\hline Hungary & 5 & 3 & 8 & 1995 & NA & - & - & - \\
\hline India & 36 & 96 & 132 & 1992 & 1986 & 1992 & 1993 & 15 \\
\hline Indonesia & 15 & 47 & 62 & 1992 & 1989 & 1989 & 1996 & 1 \\
\hline Israel & 5 & 15 & 20 & 1997 & 1992 & 1993 & - & - \\
\hline Korea & 114 & 69 & 183 & 1991 & 1984 & 1992 & 1993 & 7 \\
\hline Malaysia & 75 & 79 & 154 & 1988 & 1987 & 1988 & 1992 & 6 \\
\hline Mexico & 35 & 11 & 46 & 1989 & 1981 & 1989 & 1991 & 16 \\
\hline Pakistan & 8 & 28 & 36 & 1994 & 1991 & 1991 & - & - \\
\hline Peru & 1 & 7 & 8 & 1997 & NA & 1992 & 1994 & 1 \\
\hline Philippines & 18 & 28 & 46 & 1991 & 1987 & 1991 & 1995 & 4 \\
\hline Poland & 2 & 12 & 14 & 1996 & 1995 & - & - & - \\
\hline Portugal & 13 & 13 & 26 & 1989 & 1987 & 1986 & - & - \\
\hline Russia & 9 & 8 & 17 & 1997 & NA & - & 1997 & 5 \\
\hline Sth Africa & 61 & 50 & 111 & 1992 & 1994 & 1996 & 1994 & 22 \\
\hline Sri Lanka & 6 & 0 & 6 & 1995 & NA & 1991 & - & - \\
\hline Taiwan & 47 & 75 & 122 & 1991 & 1986 & - & 1992 & 17 \\
\hline Thailand & 38 & 96 & 134 & 1990 & 1985 & 1987 & 1997 & 5 \\
\hline Turkey & 10 & 10 & 20 & 1989 & 1989 & 1989 & 1998 & 1 \\
\hline Venezuela & 1 & 0 & 1 & 1994 & NA & 1990 & 1991 & 1 \\
\hline Total & 602 & 830 & 1,432 & & & & & 131 \\
\hline
\end{tabular}

country fund is available for the country, the official liberalisation date of the country, and the first year in which a sample firm in the country cross-lists in the United States as an American depositary receipt (ADR). Country fund data is sourced from Bekaert et al. (2005) and Patro (2005). Official liberalisation dates are taken from Bekaert et al. (2005). All information on cross-listed firms is sourced from the Bank of New York, and cross-referenced with information from Deutsche Bank, JP Morgan, the New York Stock Exchange, and Nasdaq.

We employ Tobin's $q$ to measure firm value, where Tobin's $q$ is defined as the book value of debt plus market capitalisation divided by the book value of assets. 
Like Gozzi et al. (2008), we ultimately deviate away from the original definition of Tobin's $q$ by proxying for market value of debt by using its book value counterpart, and measure the replacement cost of assets as the book value of assets. Book value of debt is calculated as the book value of total assets less the book value of equity. Doidge et al. (2004, 2009), Gozzi et al. (2008), Beiner et al. (2006), and Barontini and Caprio (2006) also use Tobin's $q$ to proxy for firm value in their studies on the valuation effects of international cross-listing, internationalisation, corporate governance, and corporate ownership structure, respectively. All firm-level financial information is sourced from Worldscope for each year from 1980 to 2003. We control for firm and industry related factors commonly employed in other studies using Tobin's $q$ (see Doidge et al., 2004, 2009: and Gozzi et al., 2008). We use the average (geometric) sales growth (inflationadjusted) over the last two years and global industry $q$ to account for firm and industry growth, respectively. Based upon primary standard industry classifications, the (yearly) mean global industry $q$ is calculated as the average $q$ of all global firms within each classification. ${ }^{5}$ We use the log of sales (inflation-adjusted and in \$US), rather than total assets (given the definition of Tobin's $q$ ) to control for firm size. Finally, we exclude financial firms since these firms are more likely to be valued differently from nonfinancial firms.

\section{Investability and Firm Value}

This section presents the main results on investability and firm value. We begin with univariate comparisons. We then proceed to panel regression estimates (pooled ordinary least squares and firm-fixed effects) of the effect of investability on firm value and its components.

\subsection{Year-by-year valuation comparisons}

In Table 2 we compare the value of investable to noninvestable firms in each year from 1988-2003. To compare investable firms to noninvestable firms, we do the following: first, the mean and median value of each group is given for each year. For each year, we calculate the difference in means (and medians) for each group, and test whether the differences in the mean (and median) between the two groups is statistically significant in each year using a t-test (z-test for medians). In addition, we calculate the relative $q$ (mean and median-adjusted) for each firm for each year from 1988 to 2003. The meanand median-adjusted relative $q$ is calculated as the $q$ of each investable firm divided by the mean (or median) $q$ of all noninvestable firms in the firm's home country. A value of relative $q$ greater than one indicates that the investable firm is worth more than its average (or median) counterpart noninvestable firm.

\footnotetext{
${ }^{5}$ Firms are designated into one of thirteen industries based on the following classifications using 4-digit SIC codes: Agriculture and Food (0100-0999 \& 2000-2111); Mining and Construction (1000-1999, excluding 1300-1399); Textiles and Printing/Publishing (2200-2799); Chemicals (2800-2824, 2840-2899); Pharmaceuticals (2830-2836); Extractive (2900-2999, 1300-1399); Durable Manufacturers (3000-3999, excluding 3570-3579); Transportation (4000-4899); Utilities (4900-4999); Retail (5000-5999); Services (7000-8999, excluding 7370-7379); Computers (7370-7379, 3570-3579, 3670-3679); Public Administration $(9000+)$.
} 


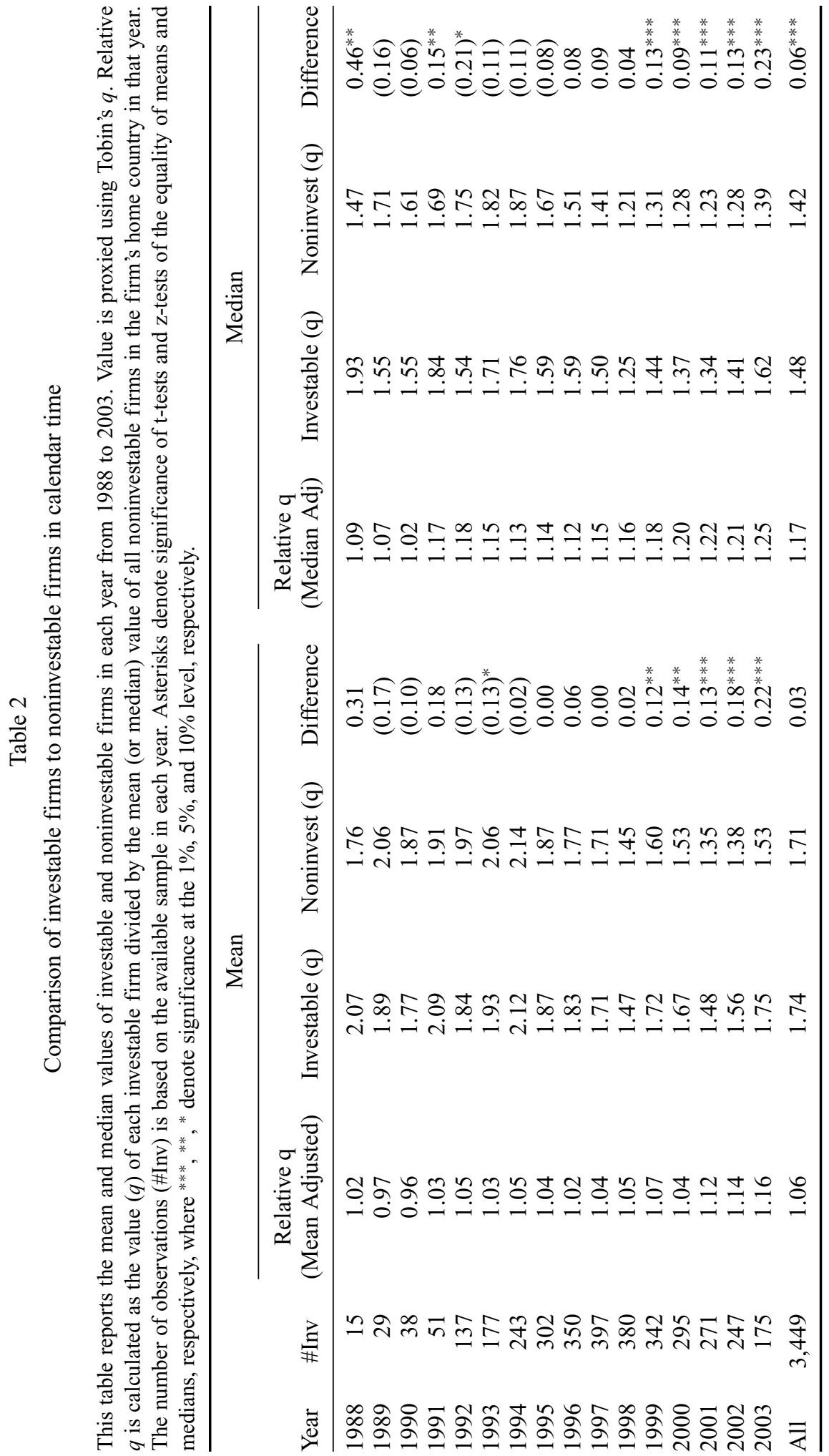


Table 2 shows that the average investable firm is valued more highly than the average noninvestable firm in all but five years. We reach similar conclusions when we use mean-adjusted relative $q$, which indicates that investable firms are worth more than noninvestable firms in all but two years. In general, the median investable firm is also worth more. Investable firms only begin to become worth more than noninvestable firms in the later part of the sample. For both means and medians, from 1999 onward investable firms are worth significantly more than noninvestable firms.

Over the entire sample period, the average (median) investable firm has a valuation premium of $0.03(0.06)$ relative to noninvestable firms. This difference is statistically significant only for the median. In addition, the mean- and median-adjusted relative $q$ measures are both greater than one for the entire sample period. Although the evidence in Table 2 suggests that investability is associated with higher firm value, the results should be interpreted cautiously given that these univariate comparisons do not control for other factors that may influence firm value. We control for these factors in regression estimates in Section 3.3.

\subsection{Event-time valuation comparisons}

Table 3 compares the value of investable firms to noninvestable firms, not in calendar time, but in event time. The event-time comparison can shed light on whether there is a significant change in firm value after firms become investable, or if valuation premia exist before firms become investable. We denote the year in which a firm first becomes investable as 'Year 0', and compare the value of investable to noninvestable firms in each year up to five years prior to, and five years after becoming investable. We compare the value of investable to noninvestable firms in an identical manner to the calendar-year comparisons presented in Table 2. First, we calculate the mean (or median) abnormal value of investable firms relative to noninvestable firms in each event year. Abnormal value is calculated as the value of each investable firm in each year less the mean (or median) value of noninvestable firms in the same year. In the remaining columns, we calculate the average mean- and median-adjusted relative value of investable firms in each event year. The final column of Table 3 reports the number of investable firms available in each event year.

Table 3 suggests that firm value does not increase after firms become investable. In fact, the average investable firm is worth relatively less after becoming investable, although the difference is not statistically significant. The value of investable firms appears to peak just prior to becoming investable, but falls off thereafter. The statistically significant valuation premia enjoyed by investable firms over noninvestable firms begin at least five years prior to becoming investable and end two years after becoming investable. The fact that the valuation premium exists prior to the event of becoming investable suggests that investability may not have a causal effect on firm value (although if the market can anticipate which firms become investable, some causality may be attributed to investability). The decline in value for investable firms is large enough that the median firm is worth statistically less than the median noninvestable firm five years after becoming investable. The last three rows of Table 3 summarise the neutral effect that investability has on firm value. The last three rows compare the (abnormal) value for the pre- and post-investability periods. The last row calculates the difference between both periods. On both an absolute and relative basis, firms that become investable are not worth more than firms that do not become investable. 
Table 3

Abnormal performance of investable firms relative to noninvestable firms in event time

This table reports the mean and median abnormal value of investable firms relative to the value of noninvestable firms in event time. The event window is defined as an eleven-year period around the event year (i.e., Year 0 is the first year that a firm becomes investable). Abnormal value is calculated as the mean (or median) of the value of investable firms less the mean (or median) value of noninvestable firms in the same year. Value is proxied using Tobin's $q$. Also reported are mean and median relative $q$, where relative $q$ is calculated as the value ( $q$ ) of each investable firm divided by the average value of all noninvestable firms in the firm's home country. The number of observations (\#Inv) is based on the available sample in each event year. Asterisks denote significance of t-tests and z-tests of the equality of means and medians, respectively, where ${ }^{* * *},{ }^{* *},{ }^{*}$ denote significance at the $1 \%, 5 \%$, and $10 \%$ level, respectively.

\begin{tabular}{lcccccr}
\hline & \multicolumn{2}{c}{ Tobin's $q$} & & Relative $q$ (Average) & \\
\cline { 2 - 3 } & $\begin{array}{c}\text { Mean } \\
\text { Abnormal } \\
\text { Value }\end{array}$ & $\begin{array}{c}\text { Median } \\
\text { Abnormal } \\
\text { Value }\end{array}$ & & $\begin{array}{c}\text { Mean } \\
\text { Adjusted }\end{array}$ & $\begin{array}{c}\text { Median } \\
\text { Adjusted }\end{array}$ & \#Inv \\
\hline-5 & $0.20^{* *}$ & $0.09^{*}$ & & 1.06 & 1.18 & 126 \\
-4 & $0.19^{* *}$ & $0.11^{* *}$ & & 1.09 & 1.21 & 185 \\
-3 & $0.13^{* *}$ & $0.17^{* * *}$ & & 1.06 & 1.17 & 247 \\
-2 & $0.27^{* * *}$ & $0.20^{* * *}$ & & 1.11 & 1.24 & 363 \\
-1 & $0.42^{* * *}$ & $0.37^{* * *}$ & & 1.19 & 1.32 & 577 \\
0 & $0.30^{* * *}$ & $0.22^{* * *}$ & & 1.16 & 1.27 & 602 \\
1 & $0.12^{* * *}$ & $0.14^{* * *}$ & & 1.08 & 1.19 & 568 \\
2 & $0.10^{* *}$ & $0.08^{* * *}$ & & 1.05 & 1.16 & 520 \\
3 & 0.04 & 0.02 & & 1.02 & 1.13 & 468 \\
4 & $(0.01)$ & $(0.05)$ & & 1.00 & 1.10 & 455 \\
5 & $(0.02)$ & $(0.06)^{*}$ & & 1.00 & 1.10 & 439 \\
All pre-investable & $0.40^{* * *}$ & $0.30^{* * *}$ & & 1.11 & 1.24 & 1,902 \\
All post-investable & 0.03 & $0.06^{* * *}$ & & 1.06 & 1.17 & 3,449 \\
Difference (Post-Pre) & $(0.37)$ & $(0.24)$ & & $(0.05)$ & $(0.07)$ & \\
\hline
\end{tabular}

We supplement Table 3 with a graphical depiction of the evolution of firm value for investable firms in event time as reported in Figure 1. The top panel of Figure 1 outlines the evolution of value for the mean and median investable firm in each year from five years prior to five years after a firm becomes investable. The bottom panel of Figure 1 depicts the evolution of mean- and median-adjusted relative $q$ in each event year. Figure 1 again suggests that firm value peaks just before the time that firms become investable, and then steadily declines after firms become investable.

The time-series behavior of Tobin's $q$ for firms that become investable is consistent with the time-series patterns of Tobin's $q$ for firms that internationalise, as reported by Gozzi et al. (2008), and for Canadian firms that cross-list, as reported by King and Segal (2009). ${ }^{6}$ In those studies, as well as in ours, firms opening up to international

${ }^{6}$ Gozzi et al. (2008) characterise 'international' firms as those that either cross-list abroad via depositary receipt programs, or raise equity capital in major financial markets. They show that the time-series patterns depicted for their entire sample hold also for various 


\section{Tobin's q}

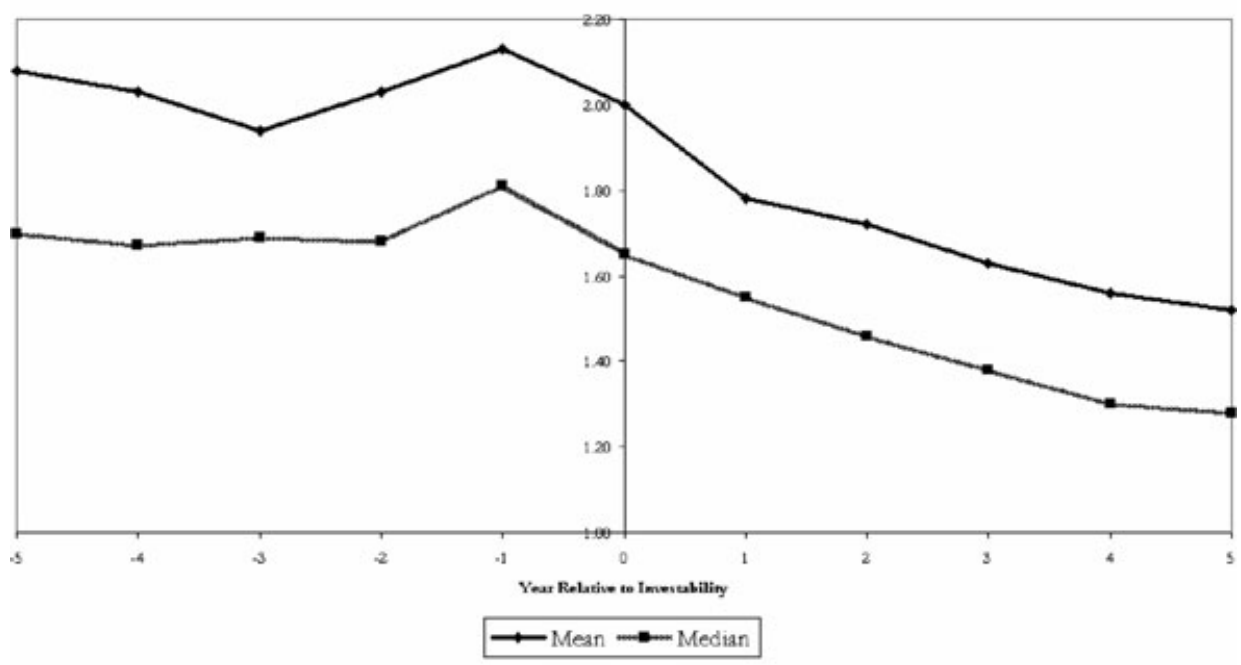

Relative Tobin's q

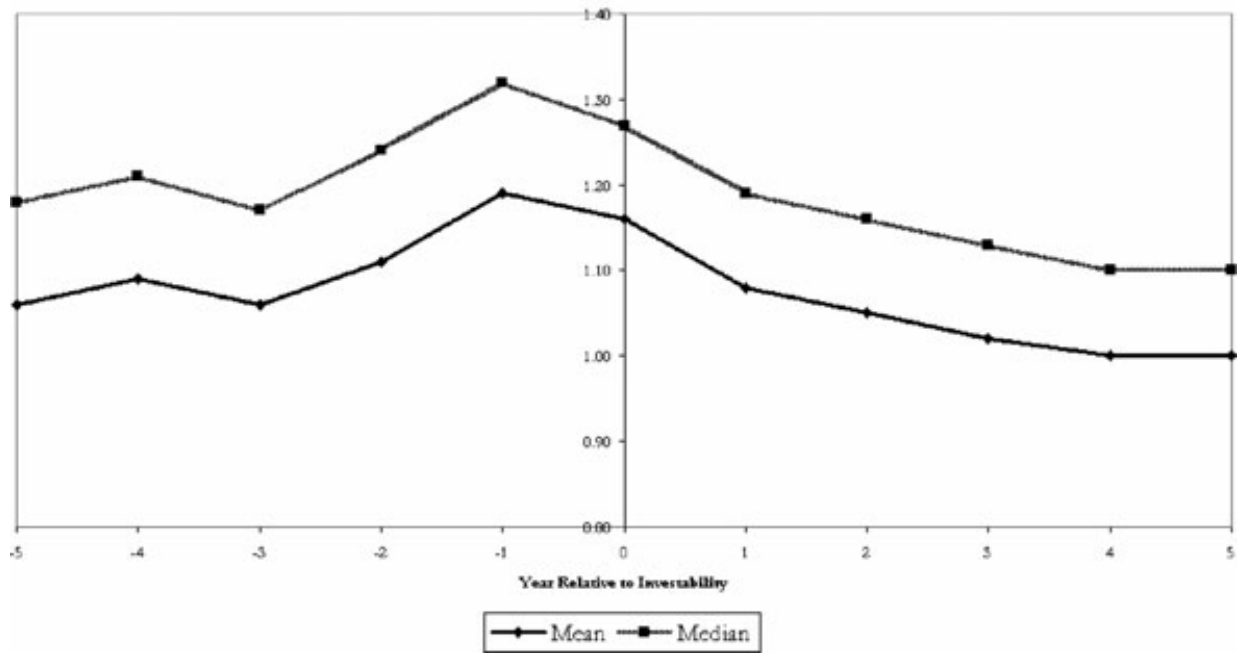

Fig. 1. Value of investable firms in event time.

The top figure displays the mean and median Tobin's $q$ of investable firms around the time of investability. Date ' 0 ' is the investable date. The bottom panel displays the mean and median-adjusted Relative Tobin's $q$ of investable firms. Mean and median-adjusted relative Tobin's $q$ is calculated as the value of each investable firm less the average/median value of noninvestable firms.

sub-samples, e.g., Level 1 and Private Placements, Exchange Lists (Level 2 \& 3), capital and non-capital raising lists. Doidge et al. (2009) do not outline graphically the time-series behaviour of value for firms that cross-list abroad (in the USA and the UK). However, the coefficient estimates from Table 10, Panel B of their working paper suggests that, like Gozzi et al. (2008), cross-listed firms experience a run-up in value prior to listing, followed by a fall-off thereafter. 
capital markets do not appear to experience a lasting increase in Tobin's $q$. The lack of a permanent increase in $q$ does not seem to be consistent with the presence of positive externalities. Nevertheless, the multivariate tests in the next section will allow us to more carefully address this issue.

\subsection{Regression analysis}

In this section we examine the relation between investability and firm value, conditional on country, industry, and firm-level controls. Specifically, we estimate the following panel (pooled ordinary least squares) regression:

$$
\text { Tobin's } q_{i t}=\alpha+\mathrm{X}_{i t} \beta+\text { Investable }_{i t}+\text { Year }_{t}+\text { Country }_{c}+\varepsilon_{i t}
$$

where Tobin's $q_{\text {it }}$ is Tobin's $q$ for firm i in year $\mathrm{t}, \mathrm{X}_{\mathrm{it}}$ is a set of firm and industry controls (sales growth, size, and global industry $q$ ), and Investable is a dummy variable that equals one if firm $i$ is investable in year $t$ and zero otherwise. Year $r_{t}$ and Country ${ }_{c}$ represent a full set of year and country dummy variables.

The coefficient estimates corresponding to Eq. (1) are presented in Table 4. Below each coefficient estimate we report t-statistics, which are calculated using standard errors clustered at the level of the firm (in parentheses). We cluster by firm to account for the time-series dependence in the residuals within firms. Clustering by firm, in combination with the inclusion of year-fixed effects (which ensure that there is no significant crosssectional dependence between firms) results in standard errors that are unbiased when both a firm effect and a time effect may be present (see Petersen, 2009). Clustered standard errors are, by construction, also robust to heteroskedasticity. In Column 1 of Table 4, we regress Tobin's $q$ on just the investable dummy along with year and country dummies. The coefficient estimate suggests that investable firms have higher values than noninvestable firms. The estimate indicates that, on average, investable firms have a Tobin's $q$ that is 0.12 higher than noninvestable firms, a difference that is significant at the $1 \%$ level. Relative to the overall average $q$ of noninvestable firms of 1.71 , the estimate indicates that investable firms have roughly a $7 \%$ valuation premium over noninvestable firms. We find that the inclusion of firm and industry-level controls does not reduce the magnitude of the coefficient estimate, nor its statistical significance. In Column 2 we include controls for firm size, firm growth, and industry growth opportunities (global industry $q$ ). In this regression the coefficient on the investable dummy increases to 0.15 , which is indicative of roughly a $9 \%$ valuation premium for investable firms. The controls are of the expected sign and are statistically significant. Firm- and industrylevel growth impact positively on valuations, whereas size is negatively correlated with Tobin's $q$.

In Columns 3 and 4 of Table 4 we control for the effects of 'indirect investability'. Specifically, in this study we examine whether foreign ownership of a firm's stock enhances value. However, foreigners may be able to take a position in a stock even if the stock is not directly investable. This can occur either though the issuance of an ADR, or through inclusion in a closed-end country fund. In order to isolate these indirect investability effects from the direct investability effects associated with stock market liberalisations, we control for both in the remaining columns of Table 4. First, we create separate dummy variables for each different ADR level (Level 1, Level 2, Level 3, and Rule 144a/RegS). The ADR dummy variables equal one in the year in which the firm first 


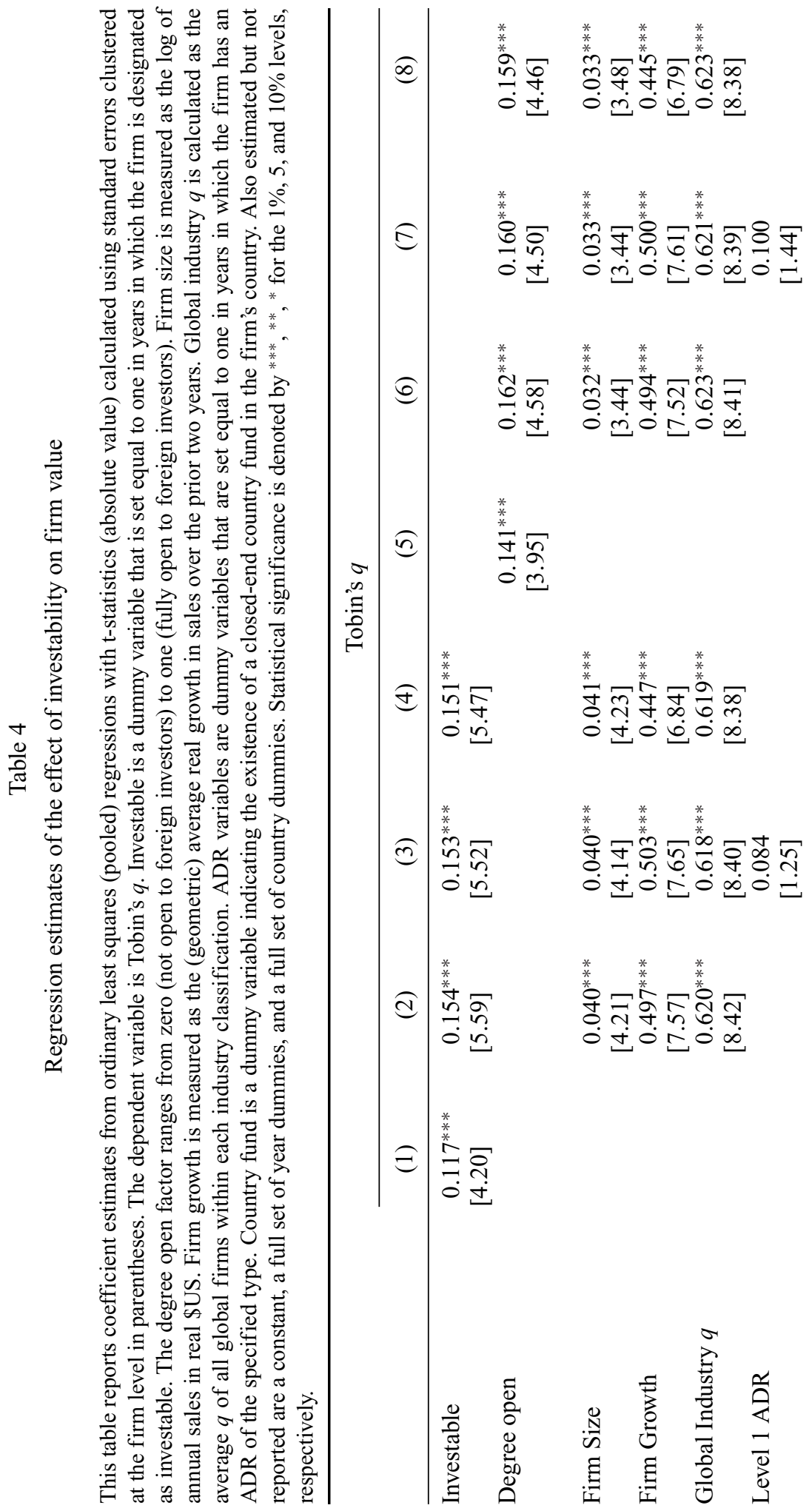




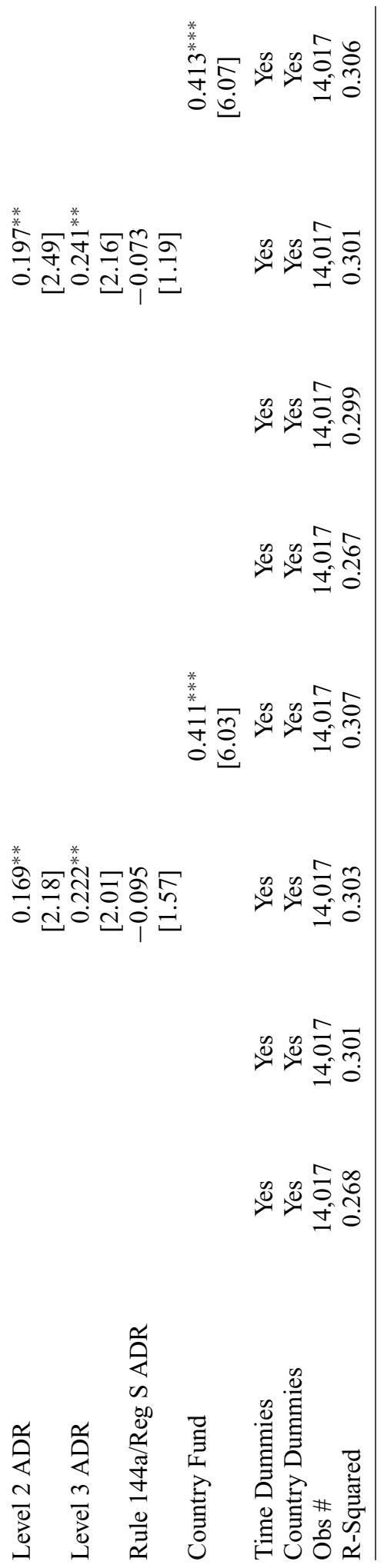


cross-lists, ${ }^{7}$ and one thereafter (the dummy becomes zero again if the firm cross-delists). We classify the ADR levels separately, since exchange-traded depositary receipts (Level 2 and 3) are associated with greater access to capital (see Lins et al., 2005 and Reese and Weisbach, 2002). ${ }^{8}$ To control for the indirect investable effects of country funds, we create a dummy variable called 'Country Fund' which equals one for every year in which a country fund is available for investment in the particular country, according to the dates outlined in the 'Key Dates' column of Table 1. Column 3 shows that Level 2 and 3 cross-listings are associated with the greatest valuation gains, which is consistent with what Doidge et al. $(2004,2009)$ term a 'cross-listing premium'. The presence of country funds (Column 4) is also associated with higher valuations. Importantly, Columns 3 and 4 show that controlling for indirect investability, either through ADRs or country funds, has very little effect on the magnitude or the statistical significance of the investable dummy.

In Columns 5 through 8 of Table 4 we repeat the regressions of Columns 1 through 4 , but replace the investable dummy with the continuous degree-open measure of investability. The results with the degree-open measure are quite similar to those using the investable dummy.

\subsection{Fixed-effects regressions}

Although the coefficient estimates from the pooled ordinary least squares regressions indicate substantial valuation premia for investable firms, these regressions fall short of establishing a causal effect of investability on value. The positive coefficient on the investable dummy could simply indicate that firms with higher valuations (for whatever reason) are those that are selected to be made open to foreign investment. The results could be affected by heterogeneity across firms that we have not sufficiently captured with the control variables in Table 4 . To address these concerns, we focus on within-firm changes by re-estimating Eq. (1), but with firm-fixed effects included, i.e., least squares dummy variable regression (LSDV). Specifically, we estimate the following two-way fixed-effects model:

$$
\text { Tobin's } q_{i t}=\alpha+\mathrm{X}_{i t} \beta+\text { Investable }_{i t}+\text { Year }_{t}+\text { Firm }_{i}+\varepsilon_{i t}
$$

where Firm $_{\mathrm{i}}$ represents firm-fixed effects, and all other variables are as explained in Eq. (1) (except that country-fixed effects are excluded).

Panel A of Table 5 presents the coefficient estimates of Eq. (2), with t-statistics, adjusted for heteroskedasticity as in White (1980), in parentheses underneath the coefficient estimates. In Columns 1 through 4 we report specifications with the same control variables as reported in Table 4, using the investable dummy as the explanatory variable. In all four specifications, the coefficient on the investable dummy is positive, but not statistically different from zero. The coefficient estimate ranges from 0.005 to 0.012 ,

\footnotetext{
${ }^{7}$ We ensure that we identify a firm's initial listing in the US. For example, many firms upgrade (e.g., Level 1 to Level 2 or 3) or downgrade (e.g., from exchange listing to Level 1) their depositary receipt level. The records displayed on the Bank of New York's website refer to a firm's current ADR listing. We consult historical records in order to identify a firm's initial listing.

${ }^{8}$ The results do not change if we create a single cross-listing dummy, rather than differentiate among the different listing types.
} 


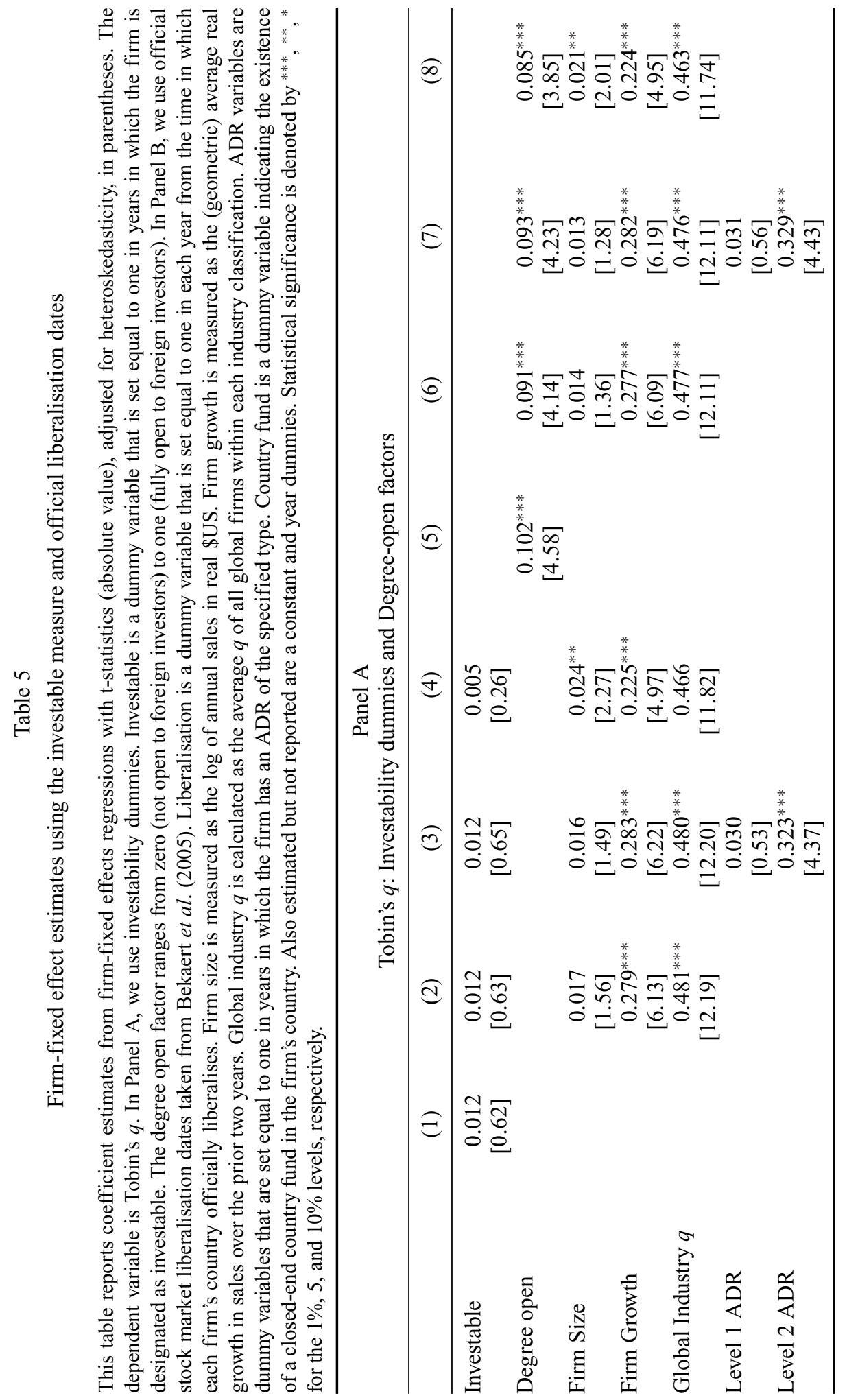




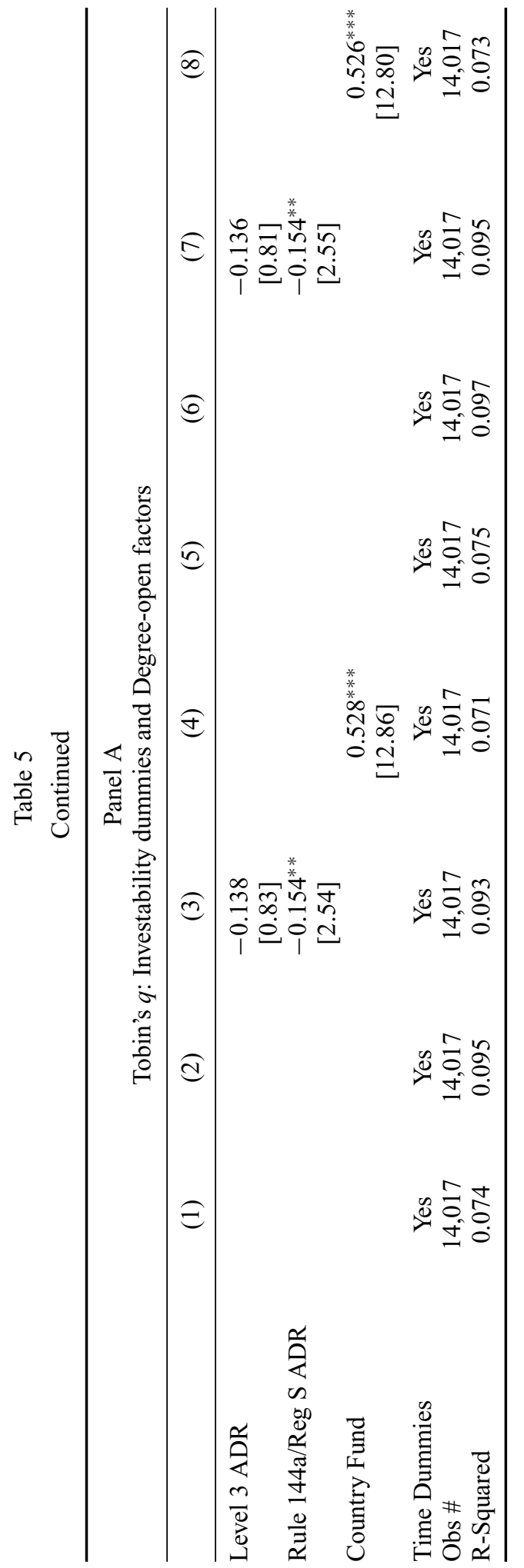




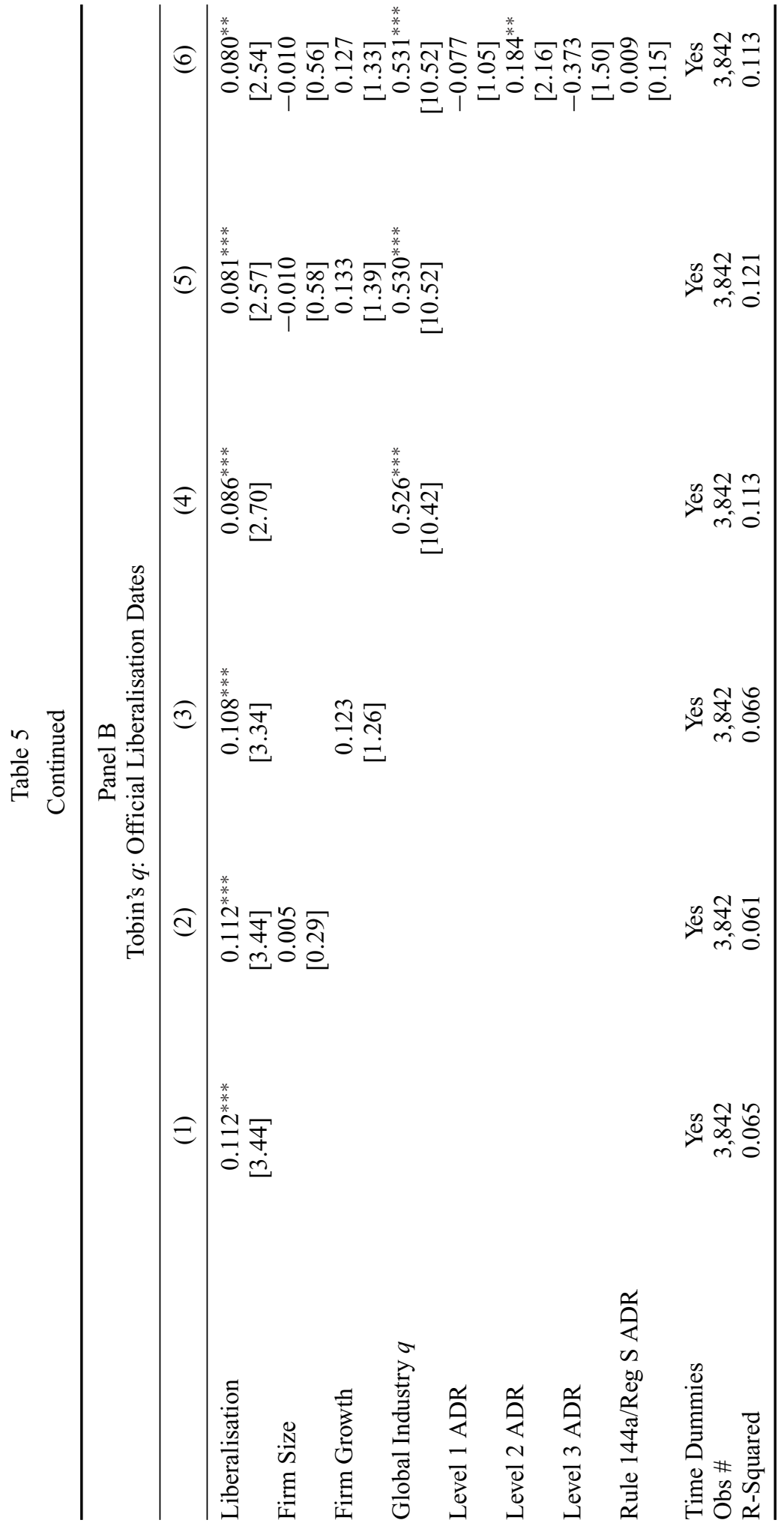


indicating relatively small valuation premia for firms that become investable. However, in Columns 5 through 8 the results using the degree-open variable tell a different story: this measure of investability is associated with large and statistically significant effects of openness to foreign investors in all four specifications.

Although the results using the two different measures of investability are consistent in that they both produce positive coefficients, the difference in the magnitude and significance of the coefficients between the two measures is somewhat puzzling. On the one hand, the results presented in Columns 1 through 4 are consistent with the findings reported in Table 3 and shown in Figure 1, which indicate that investable firms peak in value prior to becoming investable and that investability does not produce a lasting increase in Tobin's $q$. On the other hand, the results presented in Columns 5 through 8 show that the value effects of investability are strong even when using firm-fixed effects. The conflicting results are likely explained by the fact that firms can have a positive degree-open factor even when their level of openness has not reached the level that merits an investable measure of one. If investors interpret earlier indications of openness as the most import measures of investability (or eventual investability), then we would expect to see stronger effects for the degree-open measure than for the investability dummy.

For purposes of comparison, in Panel B of Table 5, we re-estimate the impact of stock market liberalisation on firm value, but now we use the official liberalisation dates from Bekaert et al. (2005). ${ }^{9}$ The official liberalisation dates are presented in Table 1 for each country. In contrast to the investability dummies and degree-open measures, the official liberalisation measures imply that all firms within each country become liberalised simultaneously. As a precursor, we outline the time-series behaviour of Tobin's $q$ in the years immediately prior to, and subsequent to the official liberalisation date. The result is depicted as Figure 2. Similar to the analysis of Tobin's $q$ presented in Figure 1 , firms appear to experience an increase in value in the period immediately prior to liberalisation, followed by a fall-off thereafter. However, in contrast to Figure 1, the magnitude of the post-liberalisation fall-off in value is much less pronounced using the official liberalisation measures. For example, using the investability dummies, the average (median) firm experiences, relative to the year in which the firm becomes investable, a fall in value of about $23 \%$ (20\% for the median firm) three years after becoming investable. The corresponding depreciation in firm value over the same period using the official liberalisation dates is a smaller $14 \%$ (and $9 \%$ for the median firm).

The regression estimates presented in Panel B of Table 5 suggest the following. First, in contrast to the results presented in Panel A for the investable dummy, but consistent with the degree-open results, we find a large (and statistically significant) effect of stock market liberalisation on firm value. The coefficient estimates on the liberalisation dummy range from 0.080 to 0.112 and are statistically significant in every specification. These results are similar to those reported for the degree-open measure. Thus, although the country-level measure has the shortcomings of not reflecting the gradual nature of liberalisation and of possibly capturing the effects of other country-level economic reforms, it produces results similar to those of the degree-open measure, which does not suffer from the same shortcomings. The liberalisation measure gives results quite

\footnotetext{
${ }^{9}$ The only difference between Panels A and B is that in Panel B we do not control for the effects of county fund availability. This is because some studies date stock market liberalisations as the year in which country funds are first available in a particular country. Consequently, official liberalisation dates and country funds are likely to be highly correlated.
} 


\section{Tobin's q}

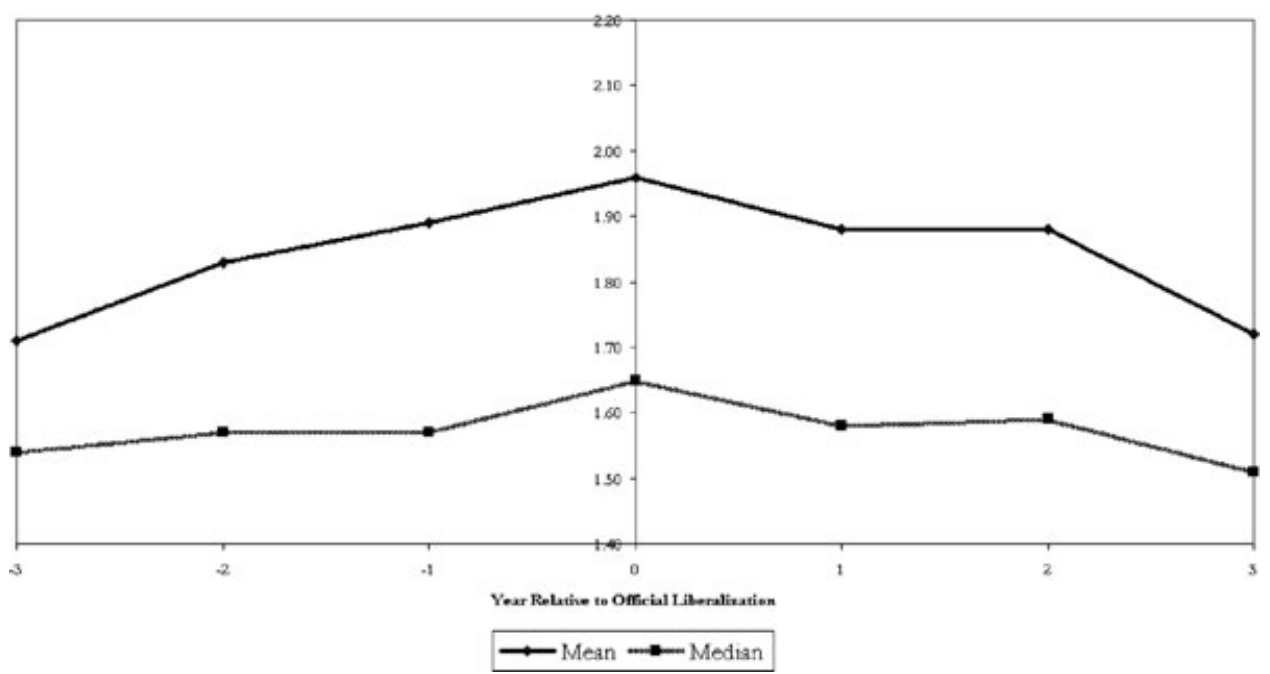

Fig. 2. Value of firms around the time of official liberalisation.

This figure displays the mean and median Tobin's $q$ of firms around the time of the official liberalisation. Date ' 0 ' is the liberalisation date as reported in Bekaert et al. (2005).

different in magnitude from the results using the investable dummy, but there is also a large difference in sample size between Panel A and Panel B, because for some countries we do not have firm-level financial data in the pre-liberalisation period. To assess the effect of different sample sizes, we replicate the results for the investable dummy in Panel A, but use only the observations available in Panel B (3,842 firm-year observations). In these results (not reported) we find a statistically significant effect of investability, with a coefficient on the investable dummy of about 0.07 . The differences in results between the liberalisation dummy and the investable dummy are not as pronounced when the samples are comparable.

As an additional robustness check on the firm-fixed effects estimates, in Table 6 we again present coefficient estimates of Eq. (2), but add two other important control variables. For a firm to receive the 'investable' designation, the firm's stock must meet two other requirements. First, the stock must exceed a market capitalisation threshold, set at an average of $\$ 50$ million over the prior 12 months. Second, the stock must meet a liquidity requirement, such that the stock must have traded at least \$20 million in value over the prior year and have traded on at least half of the trading days over the prior year. Because of these additional requirements for becoming investable, it is possible that the increased value we observe for investable firms are driven by size and liquidity factors rather than openness. To control for this possibility we add two control variables to the regression. The first, Market-cap criterion, is a dummy variable that is set to one if the firm's stock has market capitalisation of $\$ 50$ million or more in the preceding year. The second, Liquidity criterion, is a dummy variable that is set to one if the firm's stock has more than \$20 million in value traded in the preceding year and if it trades on at least 100 trading days in the previous year. 


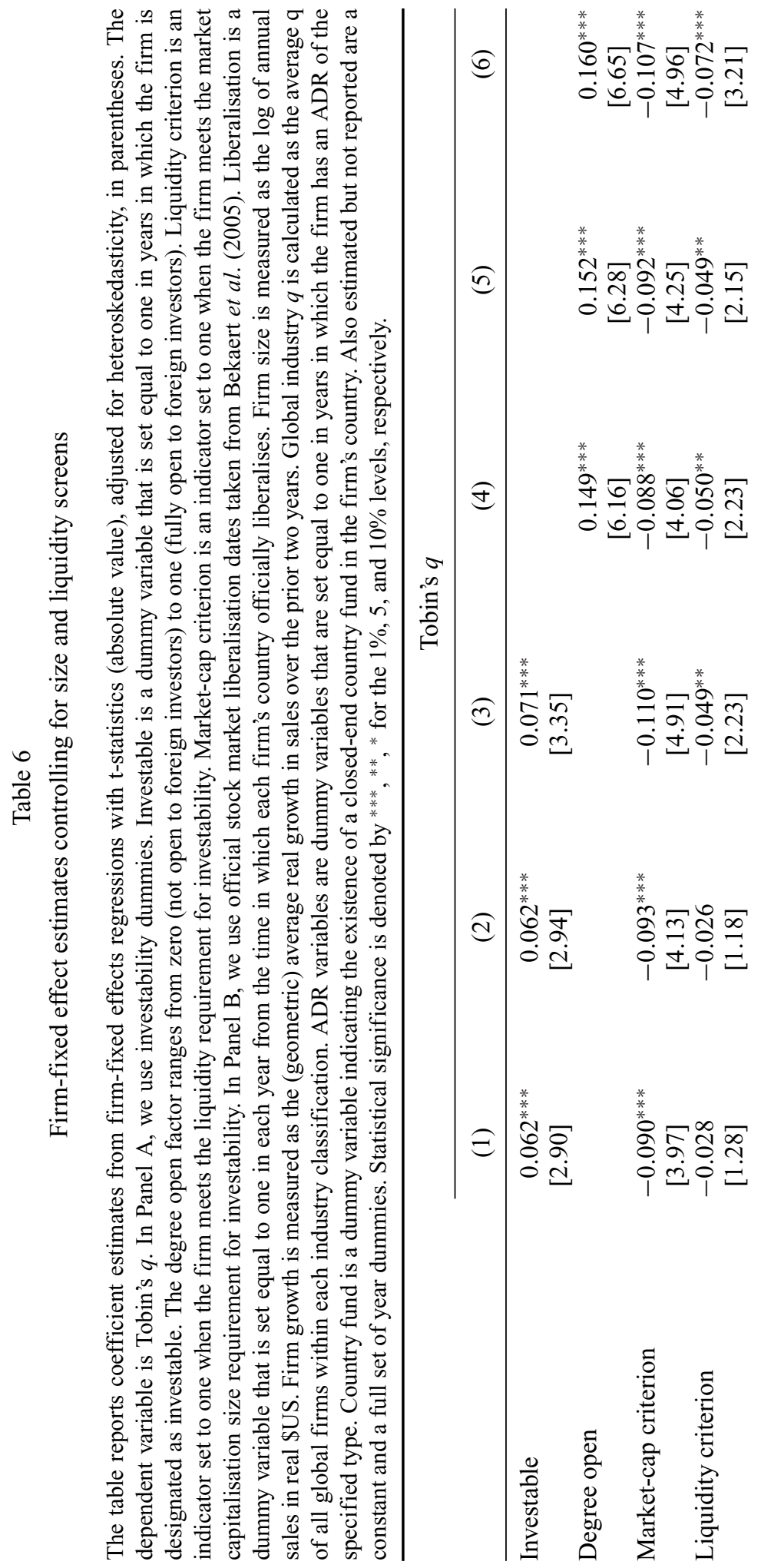




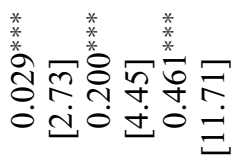

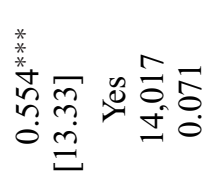

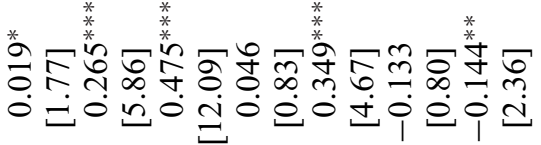

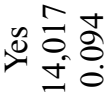

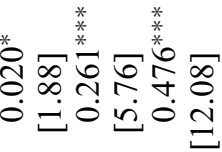

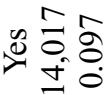

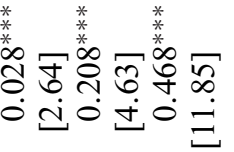

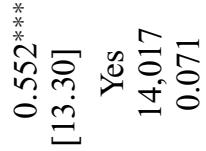

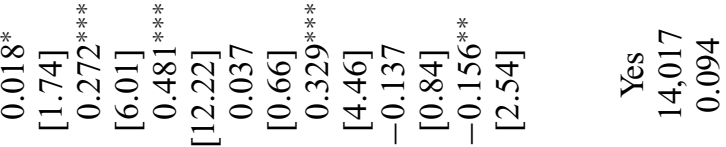

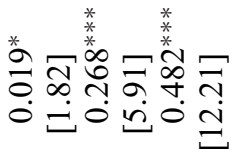

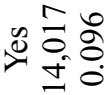

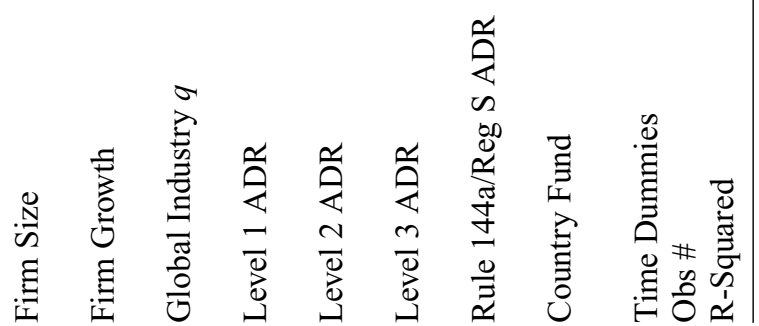


Table 6 reports results of regressions that include Market-cap criterion and Liquidity criterion as additional control variables. The first three columns show that inclusion of these control variables results in coefficients on the investable dummy that are positive and statistically significant. (The last three columns show results for the degree-open factor for comparison purposes, although the two criteria do not relate directly to the degree-open measurement.) Table 6 shows that the results are robust (and, in fact, stronger) when including controls for the other investability criteria. Thus the results appear to be driven by the openness of the stocks and not by other related factors.

\subsection{Components of Tobin's q}

In Table 3 (and Figure 1), we analysed the absolute and relative time-series behavior of the value of firms that become investable. In summary, that analysis suggests that the absolute and relative values (mean and median-adjusted) of investable firms increase in the years prior to becoming investable, and fall off thereafter. To shed further light on the evolution of value for investable firms around the time of becoming investable, we examine the components of value for the full sample of firms. Thus, we separately document the time-series behavior of the book value of assets and of market capitalisation, where both values are measured in logarithms and in \$US. Gozzi et al. (2008) perform a similar exercise in their study. We first trace out the time-series pattern of book values and market values in the eleven-year window (five years before, the year of becoming investable ' 0 ', and five years after) around the time of firms becoming investable and present these as Figures 3 and 4. In addition to calculating the absolute value of the mean and median investable firm, for each of the components of Tobin's $q$, we examine their values relative to the average values of noninvestable firms from the same country. Relative total assets and relative market capitalisation are calculated in the same manner as relative Tobin's $q$ (mean-adjusted).

Figure 3 shows that firms experience sharp increases in book values upon becoming investable. In contrast, Figure 4 demonstrates that (absolute) market capitalisation begins to fall post-investability. While firms experience a run-up in both market capitalisation and total assets prior to becoming investable, the increase in market capitalisation begins earlier and is greater than the subsequent increase in total assets.

To further investigate the effect of investability on book value and market capitalisation, we estimate firm-fixed effects regressions of the same form as in Eq. (2), but with book value and market value as the dependent variables. Table 7 presents the firm-fixed effects coefficients using log of total assets (in \$US) and log of market capitalisation (in \$US) as dependent variables, respectively. For both components, we estimate four separate regressions. First, we regress total assets and market capitalisation on the investable dummy alone. In subsequent regressions, we also control for sales growth and for the presence of ADRs and country funds. In these regressions we do not control for global industry $q$ (given that our dependent variable is no longer Tobin's $q)^{10}$ or $\log$ of sales (a proxy for firm size).

\footnotetext{
${ }^{10}$ In their paper, Gozzi et al. (2008) also perform a separate analysis of the impact of 'internationalisation' on the components of Tobin's $q$. In their pooled ordinary least squares estimates, they no longer control for global industry $q$ or firm size in these regressions (as we also do), instead using industry fixed-effects. However, this is not possible in our analysis, as we estimate firm-fixed effects, as opposed to pooled ordinary least squares regressions.
} 


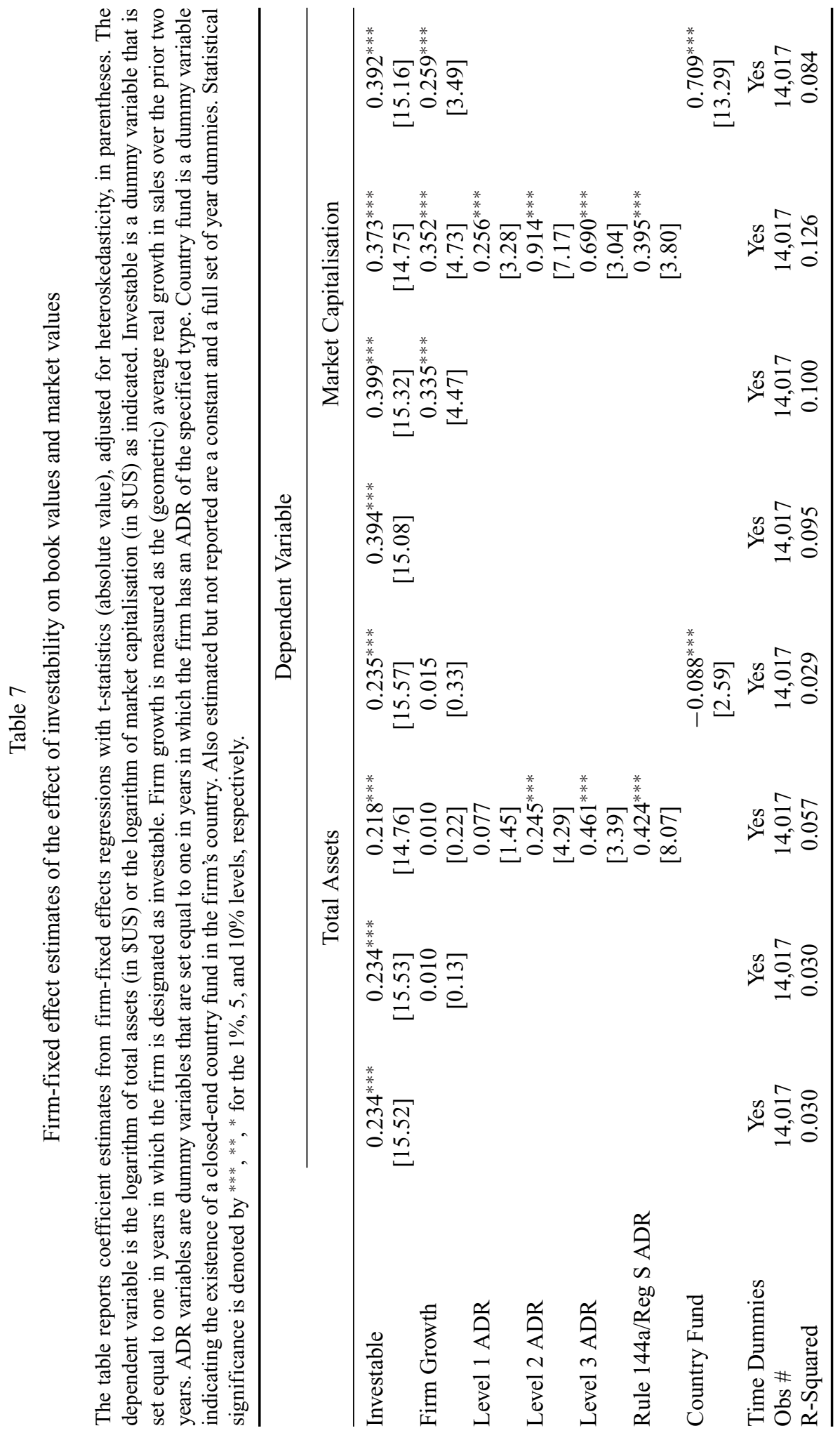




\section{Total Assets (Log US\$)}

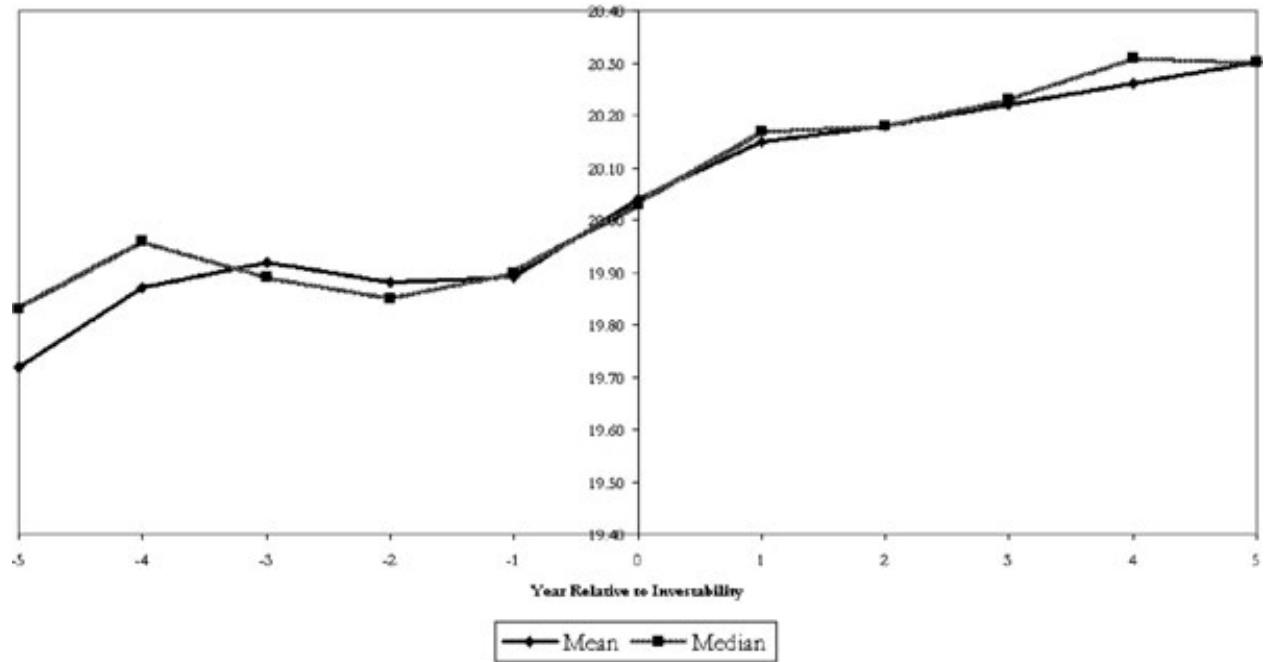

Relative Total Assets (Log US\$)

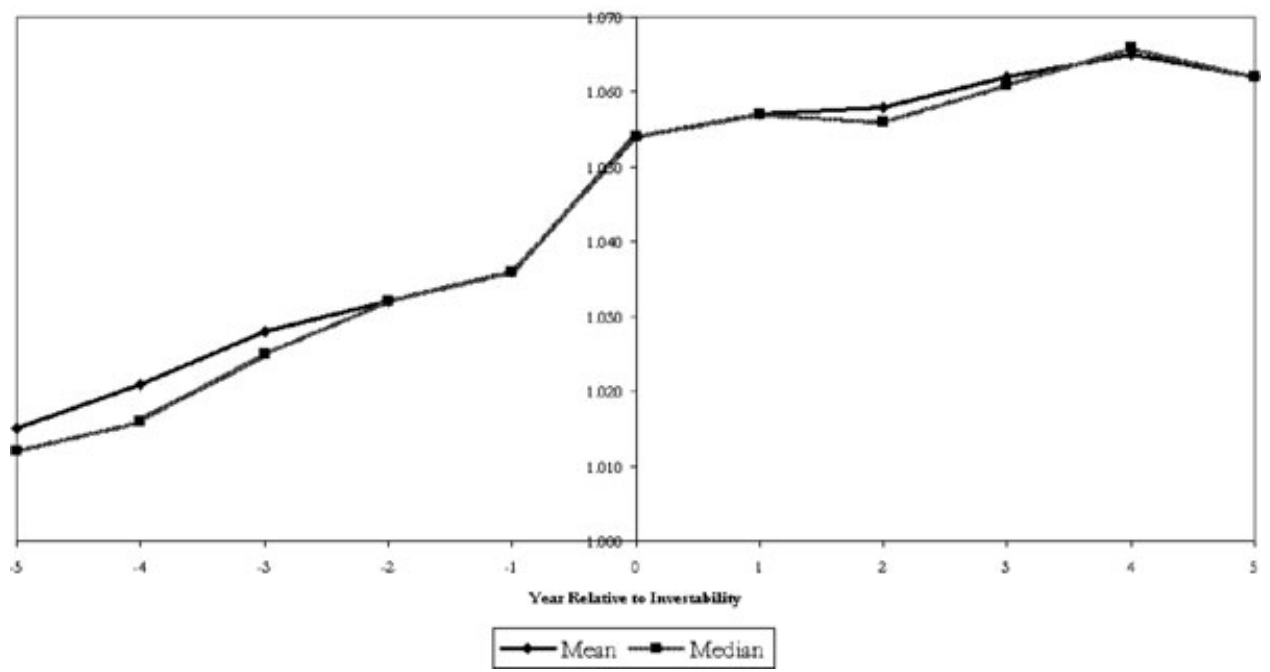

Fig. 3. Absolute and relative asset size of investable firms in event time.

The top figure displays the mean and median size of investable firms around the time of investability. Date ' 0 ' is the investable date. The bottom panel displays the mean and median relative size of investable firms. Relative size is calculated as the size of each investable firm divided by the average value of noninvestable firms.

The results from Table 7 indicate that investability is associated with an increase in both total assets and market capitalisation. In all four specifications, the coefficient estimates are positive and statistically significant at the $1 \%$ level for both components. The coefficient estimates suggest that the increase in total assets ranges from $4.38 \%$ to 


\section{Market Capitalization (Log US\$)}

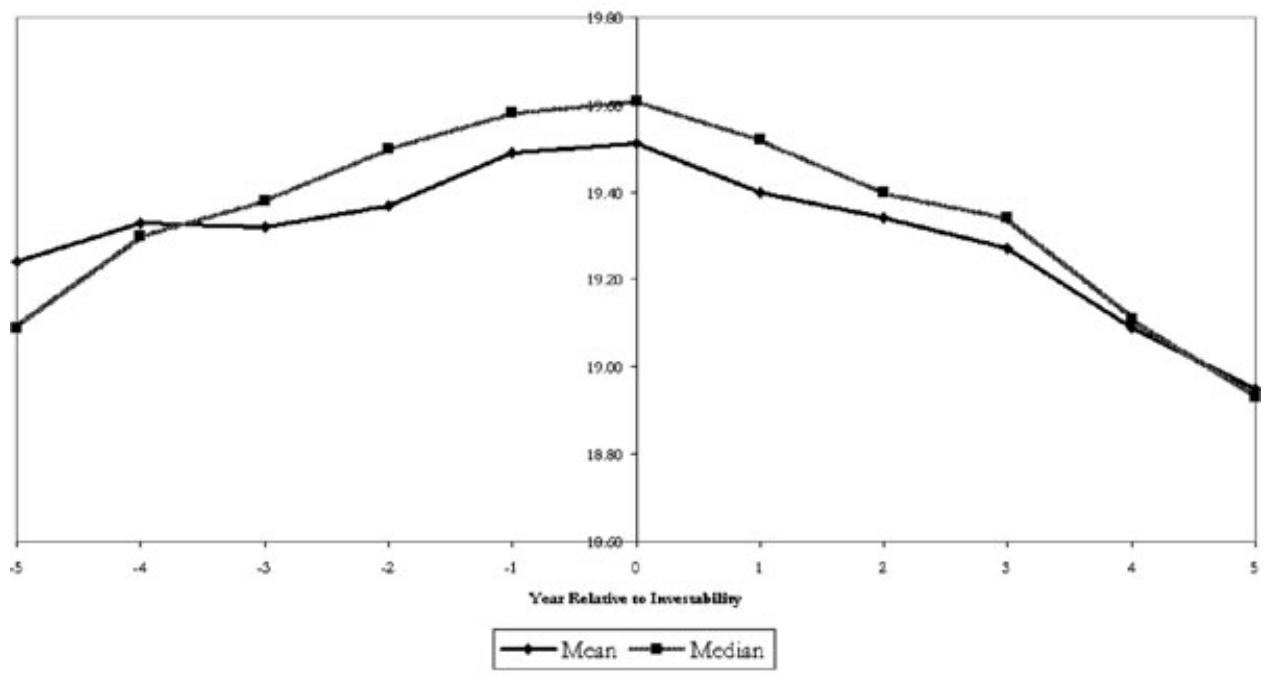

Relative Market Capitalization (Log US\$)

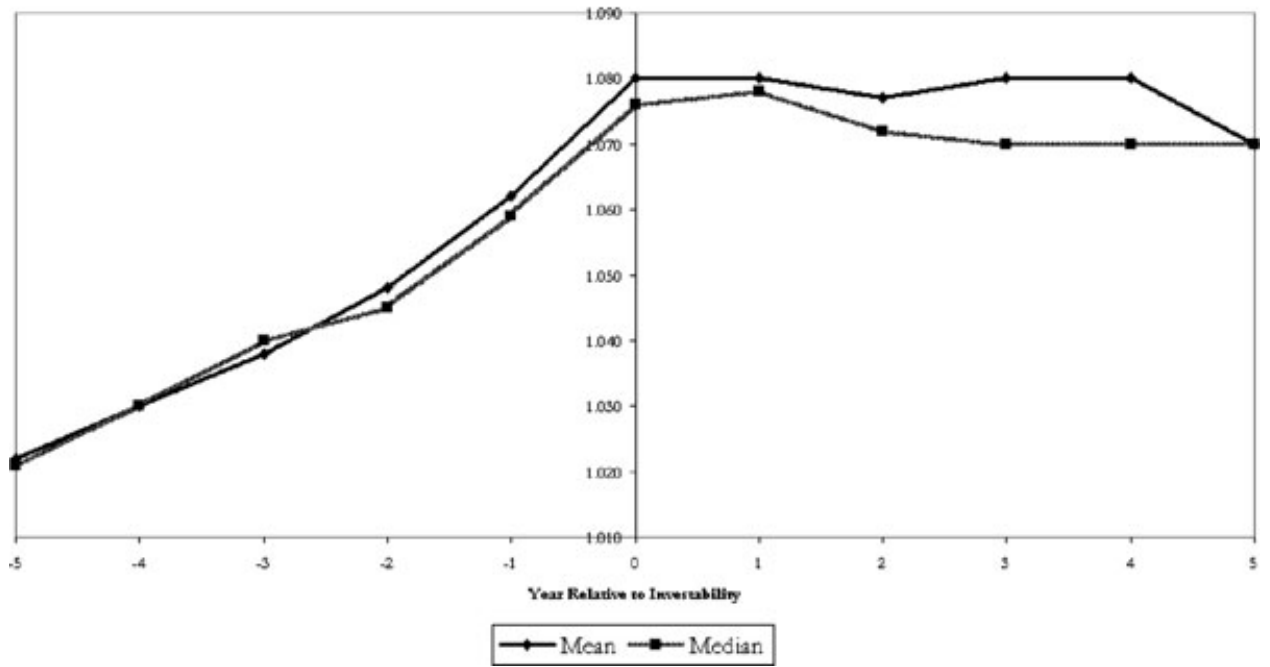

Fig. 4. Absolute and relative market capitalisation of investable firms in event time.

The top figure displays the mean and median market capitalisation of investable firms around the time of investability. Date ' 0 ' is the investable date. The bottom panel displays the mean and median relative market capitalisation of investable firms. Relative market capitalisation is calculated as the market capitalisation of each investable firm divided by the average market capitalisation of noninvestable firms.

$4.72 \%$ for the mean firm. The average investable firm experiences an increase in market capitalisation ranging from $7.17 \%$ to $7.67 \%$.

Taken together, the time-series behavior of the components of Tobin's $q$ shed light on what causes the value of investable firms to experience an appreciation prior to becoming 
investable, peak on the year immediately prior to becoming investable and fall-off thereafter. The pre-investable appreciation in firm value is caused by the appreciation in market capitalisation, which begins earlier than the corresponding appreciation in total assets, and is greater in magnitude. In contrast, the subsequent post-investability fall-off is caused by large-scale corporate expansion, coupled with a decline in market capitalisation. While investable firms experience a greater percentage increase in market capitalisation (compared to asset base) once they become investable, the increase in the firms asset base is more than sufficient to offset the increase in market capitalisation, given that for these firms, their asset base tends to be greater than their market capitalisation. (For example, in the year in which firms become investable, the median firm had assets in place of just under $\$ 498$ million, compared with a market capitalisation of just over $\$ 328$ million.) These results are similar to those documented for firms that cross-list by Gozzi et al. (2008) in that firms that internationalise also experience an appreciation in market capitalisation and an expansion in their asset base.

\section{Regression Estimates by Level of Financial Constraints}

Using the entire sample of firms, most of our tests thus far suggest that investability is associated with an increase in firm value. In this section, we examine whether there exist systematic differences across firms. Specifically, we examine whether firms that are more financially constrained, and thus have more to gain from becoming investable, become more highly valued post-investability. ${ }^{11}$ To undertake this analysis, we classify firms according to their level of financial constraints.

We first use dividend payouts as a proxy for financial constraints at the firm level. Following previous literature, we assume that firms that pay dividends are less likely to be financially constrained (see, e.g., Fazzari et al., 1988; Lang and Stulz, 1994; Chari and Henry, 2008). From Worldscope we collect data on dividend payouts for all firms in our sample. We define dividend payers as those that paid dividends in the year prior to becoming investable, and estimate separate regressions for financially constrained firms (non-dividend payers), and less-financially constrained firms (dividend payers).

Regression estimates of Eq. (2) for dividend payers and non-dividend payers are reported in Table 8. We estimate in turn regressions using Tobin's $q$, log of total assets, and $\log$ of market capitalisation as dependent variables. The number of observations in Table 8 shows that most of the firms in the sample are classified as non-dividend payers. The coefficient estimates suggest the greatest gains from stock market liberalisations accrue to financially constrained firms. Using the investable dummy, financially constrained firms have larger increases in value (Tobin's $q$ ) associated with investability, although the differences are not large (a coefficient of 0.012 for non-dividend payers compared to -0.031 for dividend payers). For asset growth and market capitalisation, the differences are more pronounced. Non-dividend payers experience a larger increase in both asset base and market capitalisation. Specifically, investability is associated with a $22 \%$ larger (comparing the coefficients of 0.247 and 0.201 ) increase in asset growth and $17 \%$ larger

\footnotetext{
${ }^{11}$ Laeven (2003) demonstrates empirically that financial liberalisation reduces financial constraints. However, his index of financial liberalisation does not account for stock market liberalisations. Kaminsky and Schmukler (2008) overcome this shortcoming, and construct an index of financial liberalisation that accounts for domestic financial sector reform, stock market liberalisations, and capital account liberalisation.
} 
Table 8

Firm-fixed effect estimates by level of dividend payout

The table reports coefficient estimates from firm-fixed effects regressions with t-statistics (absolute value), adjusted for heteroskedasticity, in parentheses. The dependent variable is Tobin's $q$, the logarithm of total assets (in \$US), or the logarithm of market capitalisation (in \$US) as indicated. Separate regressions are reported for firms that were and were not dividend payers in the year prior to becoming investable. Investable is a dummy variable that is set equal to one in years in which the firm is designated as investable. The degree open factor ranges from zero (not open to foreign investors) to one (fully open to foreign investors). Firm size is measured as the log of annual sales in real \$US. Firm growth is measured as the (geometric) average real growth in sales over the prior two years. Global industry $q$ is calculated as the average $q$ of all global firms within each industry classification. Also estimated but not reported are a constant and a full set of year dummies. Statistical significance is denoted by ***, ${ }^{* *},{ }^{*}$ for the $1 \%, 5$, and $10 \%$ levels, respectively.

\begin{tabular}{|c|c|c|c|c|c|c|}
\hline & \multicolumn{3}{|c|}{ Dividend Payers } & \multicolumn{3}{|c|}{ Non-Dividend Payers } \\
\hline & Tobin's q & Asset & MCap & Tobin's q & Asset & MCap \\
\hline Investable & $\begin{array}{r}-0.031 \\
{[0.88]}\end{array}$ & $\begin{array}{l}0.201^{* * *} \\
{[6.24]}\end{array}$ & $\begin{array}{l}0.359^{* * *} \\
{[7.18]}\end{array}$ & $\begin{array}{r}0.012 \\
{[0.79]}\end{array}$ & $\begin{array}{c}0.247^{* * *} \\
{[12.26]}\end{array}$ & $\begin{array}{c}0.423^{* * *} \\
{[11.71]}\end{array}$ \\
\hline Firm Size & $\begin{array}{c}0.010 \\
{[0.30]}\end{array}$ & & & $\begin{array}{r}0.019 \\
{[1.34]}\end{array}$ & & \\
\hline Firm Growth & $\begin{array}{c}0.179^{* *} \\
{[2.23]}\end{array}$ & $\begin{array}{c}-0.082 \\
{[1.02]}\end{array}$ & $\begin{array}{r}0.161 \\
{[1.24]}\end{array}$ & $\begin{array}{l}0.358^{* * *} \\
{[5.36]}\end{array}$ & $\begin{array}{r}0.041 \\
{[0.63]}\end{array}$ & $\begin{array}{l}0.426^{* * *} \\
{[3.92]}\end{array}$ \\
\hline Global Industry $q$ & $\begin{array}{l}0.642^{* * *} \\
{[8.05]}\end{array}$ & & & $\begin{array}{l}0.413^{* * * *} \\
{[8.03]}\end{array}$ & & \\
\hline Time Dummies & Yes & Yes & Yes & Yes & Yes & Yes \\
\hline Obs \# & 4,500 & 4,500 & 4,500 & 9,517 & 9,517 & 9,517 \\
\hline R-Squared & 0.130 & 0.031 & 0.069 & 0.084 & 0.030 & 0.121 \\
\hline Degree open & $\begin{array}{r}0.022 \\
{[0.43]}\end{array}$ & $\begin{array}{l}0.106^{* * *} \\
{[2.68]}\end{array}$ & $\begin{array}{l}0.274^{* * *} \\
{[3.48]}\end{array}$ & $\begin{array}{l}0.103^{* * *} \\
{[3.77]}\end{array}$ & $\begin{array}{l}0.147^{* * *} \\
{[6.29]}\end{array}$ & $\begin{array}{l}0.294^{* * *} \\
{[7.03]}\end{array}$ \\
\hline Firm Size & $\begin{array}{r}0.003 \\
{[0.17]}\end{array}$ & & & $\begin{array}{r}0.017 \\
{[1.17]}\end{array}$ & & \\
\hline Firm Growth & $\begin{array}{c}0.185^{* *} \\
{[2.29]}\end{array}$ & $\begin{array}{c}-0.106 \\
{[1.31]}\end{array}$ & $\begin{array}{r}0.123 \\
{[0.95]}\end{array}$ & $\begin{array}{l}0.352^{* * *} \\
{[5.27]}\end{array}$ & $\begin{array}{r}0.028 \\
{[0.42]}\end{array}$ & $\begin{array}{l}0.401^{* * *} \\
{[3.65]}\end{array}$ \\
\hline Global Industry $q$ & $\begin{array}{l}0.644^{* * *} \\
{[8.09]}\end{array}$ & & & $\begin{array}{l}0.408^{* * *} \\
{[7.92]}\end{array}$ & & \\
\hline Time Dummies & Yes & Yes & Yes & Yes & Yes & Yes \\
\hline Obs \# & 4,500 & 4,500 & 4,500 & 9,517 & 9,517 & 9,517 \\
\hline R-Squared & 0.132 & 0.004 & 0.027 & 0.087 & 0.001 & 0.057 \\
\hline
\end{tabular}

(comparing the coefficients of 0.423 and 0.359 ) increase in market capitalisation. ${ }^{12}$ Using the degree-open measure, the results are similar, except that here the increase in Tobin's $q$ for non-dividend payers is much larger and statistically significant (at the $1 \%$ level).

The finding that non-dividend payers experience a larger increase in asset growth upon becoming investable, relative to dividend payers, is indicative of stock market

${ }^{12}$ Mitton (2006) also finds that non-dividend payers invest more upon becoming investable. 
liberalisation playing a role in reducing financial constraints for emerging market firms. If one of the benefits of stock market liberalisation is that it opens a new financing channel, then the effects of liberalisation would be expected to be stronger for firms that are in greater need of additional financing.

Finally, we investigate the effect of one other firm-level measure of financial constraints, investment-to-cash flow sensitivity. Following previous literature, we assume that financial constraints are increasing in investment-to-cash flow sensitivities (see, e.g., Fazzari et al., 1988). We classify investable firms as financially constrained if their pre-investable investment-to-cash flow sensitivity is above the sample median. We estimate the investment-to-cash flow sensitivity for each firm from a regression of investment (capital expenditures to book assets) on cash flow (free cash flow to book assets) and lagged growth opportunities (market to book assets). Regression estimates of Eq. (2) for above- and below-median investment-to-cash flow sensitivities are reported in Table 9. As in Table 8, we estimate regressions using Tobin's $q$, total assets, and market capitalisation as dependent variables. The coefficient estimates again suggest the greatest gains from stock market liberalisations accrue to financially constrained firms. Using the investable dummy, financially constrained firms have larger increases in value (Tobin's $q$ ) associated with investability, and in this instance the differences are quite large (a coefficient of 0.079 for above-median investment-to-cash flow sensitivity firms compared to -0.011 for below-median investment-to-cash flow sensitivity firms). For asset growth the differences are also large, but less financially constrained firms experience the largest increase in their asset base. Changes in market capitalisations are similar across both sets of firms. Using the degree-open measure, the results are similar. Again, financially constrained firms have larger increases in value (Tobin's $q$ ) associated with investability (a coefficient of 0.104 for above-median investment-to-cash flow sensitivity firms compared to a statistically insignificant 0.074 for below-median investment-to-cash flow sensitivity firms).

Taken together, the results in Tables 8 and 9 are strongly suggestive of benefits to firms that become investable, particularly to those that have financial constraints.

\section{Conclusion}

A great deal of research has focused on the effects on performance when firms from emerging markets pass through different steps in a process of globalisation. We add to this literature by documenting the valuation effects when firms are opened to foreign equity investment. We find significant effects when firms become investable: increases in market valuations and in real investment both appear to be associated with investability. These results add to prior research on the effects of stock market liberalisations by documenting stock price increases associated with liberalisation, but using a firm-specific, rather than marketwide, measure of openness. The effects of investability on market valuations and investment are particularly strong for firms that are subject to financial constraints prior to becoming investable. Although our results do not definitively establish the presence of a causal effect of investability on firm value (as measured by Tobin's $q$ ), the firm fixed-effects regression and cross-sectional tests that we employ provide some assurance of a causal effect. Our results appear to be consistent with the predictions of standard international asset pricing models as well as with the presence of positive externalities arising from the liberalisation process. In the end, although our findings do not address other potential risks of opening up to foreign 
Table 9

Firm-fixed effect estimates by level of financing constraints using investment-to-cash

flow sensitivities

The table reports coefficient estimates from firm-fixed effects regressions with t-statistics (absolute value), adjusted for heteroskedasticity, in parentheses. The dependent variable is Tobin's $q$, the logarithm of total assets (in \$US), or the logarithm of market capitalisation (in \$US) as indicated. Separate regressions are reported for firms that were and were not above the sample median investment-to-cash flow sensitivities. Investable is a dummy variable that is set equal to one in years in which the firm is designated as investable. The degree open factor ranges from zero (not open to foreign investors) to one (fully open to foreign investors). Firm size is measured as the log of annual sales in real \$US. Firm growth is measured as the (geometric) average real growth in sales over the prior two years. Global industry $q$ is calculated as the average $q$ of all global firms within each industry classification. Also estimated but not reported are a constant and a full set of year dummies. Statistical significance is denoted by ${ }^{* * *},{ }^{* *},{ }^{*}$ for the $1 \%, 5$, and $10 \%$ levels, respectively.

\begin{tabular}{|c|c|c|c|c|c|c|}
\hline & \multicolumn{3}{|c|}{ Above Median I/CF Sensitivity } & \multicolumn{3}{|c|}{ Below Median I/CF Sensitivity } \\
\hline & Tobin's q & Asset & MCap & Tobin's q & Asset & MCap \\
\hline Investable & $\begin{array}{l}0.079^{* * *} \\
{[2.78]}\end{array}$ & $\begin{array}{l}0.203^{* * *} \\
{[7.91]}\end{array}$ & $\begin{array}{c}0.437^{* * *} \\
{[10.74]}\end{array}$ & $\begin{array}{c}-0.011 \\
{[0.17]}\end{array}$ & $\begin{array}{l}0.357^{* * *} \\
{[6.27]}\end{array}$ & $\begin{array}{l}0.400^{* * *} \\
{[5.04]}\end{array}$ \\
\hline Firm Size & $\begin{array}{c}-0.028^{* * *} \\
{[4.79]}\end{array}$ & & & $\begin{array}{c}-0.023 \\
{[0.90]}\end{array}$ & & \\
\hline Firm Growth & $\begin{array}{l}0.337^{* * *} \\
{[4.94]}\end{array}$ & $\begin{array}{c}-0.058 \\
{[0.82]}\end{array}$ & $\begin{array}{l}0.354^{* * *} \\
{[3.35]}\end{array}$ & $\begin{array}{l}0.283^{* * *} \\
{[2.69]}\end{array}$ & $\begin{array}{l}0.210^{* *} \\
{[2.27]}\end{array}$ & $\begin{array}{l}0.573^{* * *} \\
{[3.99]}\end{array}$ \\
\hline Global Industry $q$ & $\begin{array}{l}0.316^{* * *} \\
{[4.79]}\end{array}$ & & & $\begin{array}{c}0.187^{*} \\
{[1.86]}\end{array}$ & & \\
\hline Time Dummies & Yes & Yes & Yes & Yes & Yes & Yes \\
\hline Obs \# & 5,637 & 5,637 & 5,637 & 3,576 & 3,576 & 3,576 \\
\hline R-Squared & 0.110 & 0.054 & 0.163 & 0.136 & 0.078 & 0.104 \\
\hline Degree open & $\begin{array}{l}0.104^{* * *} \\
{[3.60]}\end{array}$ & $\begin{array}{c}0.064^{* *} \\
{[2.54]}\end{array}$ & $\begin{array}{l}0.220^{* * *} \\
{[5.15]}\end{array}$ & $\begin{array}{r}0.074 \\
{[1.00]}\end{array}$ & $\begin{array}{l}0.212^{* * *} \\
{[3.57]}\end{array}$ & $\begin{array}{l}0.239^{* * *} \\
{[2.67]}\end{array}$ \\
\hline Firm Size & $\begin{array}{c}-0.026^{*} \\
{[1.67]}\end{array}$ & & & $\begin{array}{c}-0.024 \\
{[0.96]}\end{array}$ & & \\
\hline Firm Growth & $\begin{array}{l}0.332^{* * *} \\
{[4.85]}\end{array}$ & $\begin{array}{c}-0.058 \\
{[0.80]}\end{array}$ & $\begin{array}{l}0.349^{* * *} \\
{[3.28]}\end{array}$ & $\begin{array}{l}0.286^{* * *} \\
{[2.71]}\end{array}$ & $\begin{array}{c}0.181^{*} \\
{[1.93]}\end{array}$ & $\begin{array}{l}0.540^{* * *} \\
{[3.71]}\end{array}$ \\
\hline Global Industry $q$ & $\begin{array}{l}0.312^{* * *} \\
{[4.71]}\end{array}$ & & & $\begin{array}{c}0.183^{*} \\
{[1.80]}\end{array}$ & & \\
\hline Time Dummies & Yes & Yes & Yes & Yes & Yes & Yes \\
\hline Obs \# & 5,637 & 5,637 & 5,637 & 3,576 & 3,576 & 3,576 \\
\hline R-Squared & 0.107 & 0.001 & 0.065 & 0.139 & 0.010 & 0.072 \\
\hline
\end{tabular}

investment (such as crisis susceptibility), they add to our understanding of the perceived benefits of stock market liberalisation on firm performance.

\section{References}

Bae, K.-H., Bailey, W. and Mao, C.X., 'Stock market liberalization and the information environment', Journal of International Money and Finance, Vol. 25, 2006, pp. 404-28. 
Bae, K.-H., Chan, K. and Ng, A., 'Investibility and return volatility', Journal of Financial Economics, Vol. 71, 2004, pp. 239-63.

Barontini, R. and Caprio, L., 'The effect of family control on firm value and performance: evidence from continental Europe', European Financial Management, Vol. 12, 2006, pp. 689-723.

Beiner, S., Drobetz, W. and Schmid, M. and Zimmermann, H., 'An integrated framework of corporate governance and firm valuation', European Financial Management, Vol. 12, 2006, pp. 24983.

Bekaert, G. and Harvey, C., 'Foreign speculators and emerging equity markets', Journal of Finance, Vol. 55, 2000, pp. 565-613.

Bekaert, G., Harvey, C. and Lundblad, C., 'Does financial liberalization spur growth?' Journal of Financial Economics, Vol. 77, 2005, pp. 3-55.

Chari, A. and Henry, P., 'Risk sharing and asset prices: evidence from a natural experiment', Journal of Finance, Vol. 59, 2004, pp. 1295-1324.

Chari, A. and Henry, P., 'Firm-specific information and the efficiency of investment', Journal of Financial Economics, Vol. 87, 2008, pp. 636-55.

Doidge, C., Karolyi, G.A. and Stulz, R.M., 'Why are foreign firms listed in the US worth more?' Journal of Financial Economics, Vol. 71, 2004, pp. 205-238.

Doidge, C., Karolyi, G.A. and Stulz, R.M., 'Has New York become less competitive in global markets? Evaluating foreign listing choices over time', Journal of Financial Economics, Vol. 91, 2009, pp. 253-77.

Edison, H. and Warnock, F., 'A simple measure of the intensity of capital controls', Journal of Empirical Finance, Vol. 10, 2003, pp. 81-103.

Fazzari, S., Hubbard, G. and Petersen, B., 'Financing constraints and corporate investment', Brookings Papers on Economic Activity, Vol. 1, 1988, pp. 141-95.

Gozzi, J.C., Levine, R. and Schmukler, S.L., 'Internationalization and the evolution of corporate valuation', Journal of Financial Economics, Vol. 88(3), 2008, pp. 607-32.

Henry, P., 'Stock market liberalization, economic reform, and emerging market equity prices', Journal of Finance, Vol. 55, 2000a, pp. 529-64.

Henry, P., 'Do stock market liberalizations cause investment booms?' Journal of Financial Economics, Vol. 58, 2000b, pp. 301-34.

Henry, P., 'Capital account liberalization, the cost of capital, and economic growth', American Economic Review, Vol. 93, 2003, pp. 91-96.

Kaminsky, G.L. and Schmukler, S.L., 'Short-run pain, long-term gain: financial liberalization and stock market cycles', Review of Finance, Vol. 12, 2008, pp. 253-92.

Kim, E.H. and Singal, V., 'Stock market openings: Experience of emerging economies', Journal of Business, Vol. 73, 2000, pp. 25-66.

King, M.R. and Segal, D., 'The long-term effects of cross-listing, investor recognition, and ownership structure on valuation', Review of Financial Studies, Vol. 22, 2009, pp. 2393-2421.

Laeven, L., 'Does financial liberalization reduce financing constraints?' Financial Management, Vol. 32, 2003, pp. 5-34.

Lang, L.H.P. and Stulz, R.M., 'Tobin's $q$, corporate diversification, and firm performance', Journal of Political Economy, Vol. 102, 1994, pp. 1248-80.

Lins, K., Strickland, D. and Zenner, M., 'Do non-US firms issue equity on US stock exchanges to relax capital constraints?' Journal of Financial and Quantitative Analysis, Vol. 40(1), 2005, pp. 109 33.

Mitton, T., 'Stock market liberalization and operating performance at the firm level', Journal of Financial Economics, Vol. 81, 2006, pp. 625-47.

Patro, D., 'Stock market liberalization and emerging market country fund premiums', Journal of Business, 78, 2005, pp. 135-68,

Petersen, M.A., 'Estimating standard errors in finance panel data sets: comparing approaches', Review of Financial Studies, Vol. 22(1), 2009, pp. 435-80.

Rajan, R. and Zingales, L., 'Financial dependence and growth', American Economic Review, Vol. 88, 1998, pp. 559-86. 
Reese, W. and Weisbach, M., 'Protection of minority shareholder interests, cross-listings in the United States and subsequent equity offerings', Journal of Financial Economics, Vol. 66, 2002, pp. 65104.

Stulz, R., 'Globalization, corporate finance, and the cost of capital', Journal of Applied Corporate Finance, Vol. 12, 1999, pp. 8-25.

White, H., 'A heteroskedasticity-consistent covariance matrix estimator and a direct test for heteroskedasticity’, Econometrica, Vol. 48, 1980, pp. 817-38. 